九州大学学術情報リポジトリ

Kyushu University Institutional Repository

\title{
Some Problems of the Mechanization of Paddy Land Preparation in Sri Lanka and Lessons from Japan's Experience
}

Ul luw i shewa, Rohana

Seminar of Econometric Analysis in Agriculture, Faculty of Agriculture, Kyushu University

Tsuchiya, Keizo

Seminar of Econometric Analysis in Agriculture, Faculty of Agriculture, Kyushu University

Sakai, Jun

Seminar of Agricultural Machinery, Faculty of Agriculture, Kyushu University

https://doi.org/10.5109/23807

出版情報: 九州大学大学院農学研究院紀要. 29 (4)，pp.211-256，1985-06. Kyushu University バージョン：

権利関係 : 


\title{
Some Problems of the Mechanization of Paddy Land Preparation in Sri Lanka and Lessons from Japan's Experience
}

\author{
Rohana Ulluwishewa*, Keizo Tsuchiya \\ and Jun Sakai \\ Seminar of Econometric Analysis in Agriculture and Agricultural \\ Machinery, Faculty of Agriculture, Kyushu University \\ 46-07 Fukuoka 812 (Received February 13. 1985)
}

\begin{abstract}
Sri Lanka's failure to adapt the imported tractors and attached implements to the local field conditions, and to improve the field conditions to make them suitable to the modern farm machines considerably accounts for the poor work performance evident in the mechanized paddy land preparation. Concentration of the tractor ownership in the hands of local businessmen, and the resulting contract cultivating system adversely affect the income distribution. Japan managed to avoid these problems since the very inception of the mechanization by modifing the imported tractors and attachments and by improving the field conditions. Group ownership and utilization of farm machines which is popular in Japan, enables small farmers to enjoy the benefits of the ownership right of farm machines. Therefore, Japan's experience in farm mechanization suggests that modification and improvement of imported tractors and attachments, improvement of paddy field conditions and group approach to tractor ownership may have greater potentials to solve some of the Sri Lanka's problems of mechanization.
\end{abstract}

\section{INTRODUCTION}

Mechanization of paddy land preparation in Sri Lanka is heavily criticized for its adverse impacts on income distribution and employment opportunities, and for its failure to raise the quality of work performance. The hopes that the nation kept on mechanization to raise the national paddy production seem to be rather frustrated. In Sri Lanka's effort to solve these problems, it is worthwhile to look into the experience of a country which has successfully mechanized its paddy farming sector, because the mechanization experience of such a country would suggest some measures which would be helpful to Sri Lanka to solve these problems. The paddy farming sector in Japan is somewhat similar to that in Sri Lanka in terms of the size of paddy holdings and the dependence on family labour. In Japan, though paddy holdings are small, machines are successfully used for all field operations, and all farmers, small and large, enjoy almost the same living standard. Apart from this, mechanization has considerably contributed to promote the quality of work performance. Therefore, it is worthwhile to look into the Japan's experience in paddy land mechanization in search of measures to solve some

* Present address : Department of Geography, Sri Jayawardenapura University, Nugegoda, Sri Lanka 
of the Sri Lanka's mechanization problems. It is the objective which this study is intended to achieve.

Comparative consideration of the Sri Lanka's approach to the mechanization with that of Japan would enable us to understand some mistaken policy measures taken at the introductory stage of the mechanization, and the causes of the current problems; and also such a comparative consideration would assist to find some probable measures which would be helpful to remedy those problems. Therefore, attempts will be made to point out the differences between Japan's approach and Sri Lanka's approach to mechanization and, to identify the causes for some socio-economic and technical problems. Then, it is intended to observe the measures which were taken by Japan to avoid these problems, and their relevance to Sri Lanka. Then some of the measures, which seem to be relevant, will be discussed in detail.

\section{DISCUSSION}

In Japan, agricultural development has been achieved step by step, starting from the hydraulic level, good water management, proceeding to biological development, chemical inputs and farm mechanization, respectively. This step-by-step approach seems to be consistant with the Sawada's model of the stage of development" (Figure 1).

Where $\mathrm{H}$ is hydraulic or water control, $\mathrm{B}$ is biological factors such as improved variety, organic fertilizer, $\mathrm{C}$ is chemical factors such as chemical fertilizers and pesticides, and $M$ is mechanical factors such as farm tractors and other aspects of farm mechanization. Quite similarly to this model Japan started her technological progress with human efforts to overcome the pro-



Fig. 1. Model of Development Stages. Source: Sawada, S. 1973

1) Sawada, S. 1973 
blem of water shortage or water surplus by developing hydraulic structure of water control. Later, the discovery of high yielding varieties stimulated the better methods of water control and at the same time it also encouraged the use of chemical fertilizers and consequently resulted in the adoption of farm machines. Such a step-by-step approach towards the mechanization cannot be seen in Sri Lanka. Problems involved in water shortage in the dry zone and water surplus in the wet zone are still a common phenomenon. The irrigation system which was developed in the dry zone in the ancient period began to deteriorate since $1200 \mathrm{AD}$ after the population migration from the dry zone to the wet zone. It was the beginning of this century when the state began to make effort to restore the ancient irrigation system. At the same time the state began to take steps to introduce tractors. Consequently, at present, the mechanization is in progress in the absence of a properly controlled water supply. As it has been observed in Hureegama ${ }^{2)}$ an uncertain water supply exerts negative impacts on mechanization. Farmers hesitate to use expensive mechanical power for tillage operation unless the irrigation water is available in time because subsequent water shortage would cause damage to the harvest. In such a case farmers would lose their expected harvest plus the money that they invested for mechanical ploughing. Furthermore, farmers' resistance to the consolidation of dispersely located small paddy plots into larger units, which is necessary to promote the mechanization was found to be attributable to the inequality of the tract-level distribution of irrigation water ${ }^{3)}$. The problems of water surplus in the wet zone apparently impede the use of tractors, and the excess water and resulting sinkage damage the machines. Japan successfully avoided this kind of problems because they arrived at the current advanced stage of mechanization step by step.

Japanese farmers began to shift from animal draught power to mechanical power mainly in order to save labour of which wage rates began to rise in response to the increased labour demand for the growing industrial sector 4). Farm mechanization enabled small farmers to make use of their time in the rapidly growing industrial sector and to raise their total family income. By 1977 Japanese farmers' income from secondary industry had reached the same level as their agricultural income. Small farmers obtained $80 \%$ of their income from non-farm business and only $20 \%$ from farming; large farmers obtained only $10 \%$ of their income from non-farm business and $90 \%$ from their farms. But the standard of living throughout the village was more or less equalized. In this way, farm mechanization in Japan led to more equitable distribution of rural incomes". In contrast to Japan, quite the opposite effect was noted in Sri Lanka where the farmers began to adopt mechanical power not because of the increased labour wage rates but mainly

\footnotetext{
2) Ulluwishewa, R. and K. Tsuchiya 1983

3) Karunanayake, M. 1977

4) Tsuchiya, K. 1976

5) Hemmi, K. and K. Atumi 1981
} 
because of the artificially lowered tractor hire rates coupled with the labour shortage during the rather short land preparation period. The resulting mechanization increased the income of the tractor-owned businessmen and some affluent farmers, but due to the absence of the non-farm job opportunities, income of the tractor hirers remained much the same. Therefore, the farm mechanization in Sri Lanka led to rather inequal income distribution.

Japan, at the very outset of the farm mehanization, imported tractors and implements in the same way as Sri Lanka. However, Japan's approach to the adoption of imported technology was quite different from that of Sri Lanka because Japan imported only the carefully selected types which were assumed to be suitable to her small-scale farming system, and modified and further improved the imported machines and implements in order to make them fit to the local field conditions whereas Sri Lanka started mechanization with the large scale riding tractors which were abandoned by departing British military authorities, and donated by some western countries, without appropriate modifications and improvements. Due to the differential approaches, while the Japanese farmers managed to smoothly shift from animalpowered cultivation to the mechanical-powered system without exerting heavy strain to the traditional cultural practices, in Sri Lanka, farmers' shift from animal power to mechanical power has given rise to many problems. For example, low efficiency of farm machines and poor quality of their performance are often mentioned.

Furthermore, Japan imported and locally manufactured small hand tractors of which retail prices were so low that individual farmers could afford, at least with the help of loans whereas the retail price of riding tractors imported by Sri Lanka at the introductory stage was so high that average farmers could never purchase even with the help of loans because the share to be paid by the buyer was far beyond the average farmers' capacity. Consequently, the tractor ownership in Sri Lanka has been concentrated into the hands of businessmen and some enterprising cultivators who were engaged in contract farming as a side job. They enjoyed the benefits which were provided by the state in the name of agricultural development. As it was observed in Unagaswewa village ${ }^{6)}$, this ownership pattern results in inequality in land ownership pattern too. Flow of cash from tractor hirers to tractor owners through hire charges further aggravates the peasants' living standard. Apart from this, the hirers' lack of command over the tractor operator, who is necessarily a person employed by the owner, makes it difficult to bring the work performance to the farmers' own satisfaction. In Japan, at the initial stage of the mechanization the retail price of a tractiontype hand tractor was almost equal to the price of a cattle?'. Therefore, average farmers could manage to purchase hand tractors for their own farm works. Later, at the stage of the large scale riding tractors, the potential buyers organized themselves into groups and purchased tractors for joint use.

6) Ulluwishewa, R. and K. Tsuchiya 1984

7) Sakai, J. 1984 (a) 
In this way, all the time, farmers themselves were tractor owners.

In Japan, farm power transition from man power to animal power, and then animal power to mechanical power occurred together with the land improvement projects which improved the field conditions in order to suit the fields to the new type of farm power and implements. In contrast, the paddy field conditions in Sri Lanka still remain unchanged. Therefore, modern farm machines and implements are used in paddy fields which were developed for traditional farming methods. For example, the size and shape of field lots, quality of farm roads, bearing capacity of the sub-soils and the irrigation and drainage channels still remain much the same. Usage of modern tractors and implements in these traditional-styled fields results in low efficiency and poor quality of performance.

In this way, the approach to the mechanization of paddy land preparation in Sri Lanka was different from that in Japan, and it seems that the mistakes done at the introductory stage have caused many socio-economic and technical problems. Mechanization in Japan has not given rise to this kind of problems because, as it was seen, her approach was different, and it was appropriate to the situation. In the process of mechanization, Japan adopted some suitable measures to avoid some of the problems which are now seen in Sri Lanka. Some of these measures, which are seen to be feasible in Sri Lanka, deserve further attention. Therefore, next section deals with a number of measures adopted by Japan at the introductory stage of her mechanization, and their potential capacity to solve some of Sri Lanka's problems. These measures entail following themes.

i . Modification and improvement of the imported tractors and implements.

ii. Joint use of farm machines.

iii. Land improvement.

1. Modification and improvement of the imported tractors and implements.

Both Japan and Sri Lanka, at the introductory stage of the mechanization of paddy land preparation, imported tractors and implements. Japan imported the tractors which were purposively selected, and she modified them and further improved in order to make them suit to the local field conditions. But, Sri Lanka adopted the imported tractors and implements as they were. Due to the differential approaches, while the Japanese farmers managed to smoothly shift from animal-powered cultivation to the mechanical-powered cultivation, giving minimum strain to the contemporary cultural practices and traditions, in Sri Lanka, the farmers' transfer from animal power to mechanical power, has given rise to many problems. This section deals with this phenomenon. In this section, attempts will also be made to find possible solutions from Japan's experience.

At the introductory stage of farm mechanization in Japan, tractors and attached implements were imported from Europe and the USA while in the case of Sri Lanka, it was mainly from the Great Britain. Agriculture in Europe and in the USA, is dominated by upland farming which is basically 
different from lowland farming system which is practised in Japan and in Sri Lanka. Since the tractors and implements which were produced in Europe and in the USA, were designed to meet the requirements of the upland farming, appropriate modifications are inevitable if they are efficiently used for the Asian lowland farming. At this point it is necessary to understand the basic differences between the two distinct farming systems.

While the upland farming system is dominated by cereals, mainly wheat, fruits and vegetables, rice is the major crop cultivated under the lowland farming system. In the case of the former, the operational scale is considerably large whereas it is rather small in the case of the latter. Apart from this, a vast differences can be seen in the principles on which the land preparation is based". In the case of upland farming the hard pan (plough pan) under the top soil layer has to be destroyed by deep ploughing in order to facilitate the roots to penetrate into subsoils in search of water. In contrast to the upland farming, paddy fields are provided with irrigation water so that a layer of water is retained on the top soils throughout the planting and sowing periods. Therefore, the hard pan has to be carefully maintained in paddy fields because it is necessary to keep the irrigation water upon it. Also, it prevents the irrigation water from percolating into the subsoils with the dissolved nourishments. Apart from this, the hard pan is necessary to support the men, cattle and machines working upon it. Destruction of the hard pan causes difficulties for men and machines to work on paddy fields due to the sinkage. Also, the rapid percolation of water and nourishments into the deep subsoils will waste the costly irrigation water, and will reduce the yield.

Therefore, in contrast to the upland farming, the lowland farming need not deep ploughing. Therefore, while deep ploughing is practised in upland farming, shallow ploughing is adequate and suitable for lowland farming because it makes the top soils soft without destroying the hard pan. It is common knowledge to have $20-30 \mathrm{~cm}$ or more depth of ploughing in modern upland farming in general. However, in Asian countries, depth of ploughing in paddy fields is not so deep, and it is usually about $10 \mathrm{~cm}$ in many tropical countries and $13-18 \mathrm{~cm}$ in China, Korea and Japan".

Furthermore, in the case of lowland farming, field surface must be perfectly flat whereas it is not necessarily to be flat in the case of upland farming. The recommended degree of flatness in Japan is less than $\pm 5 \mathrm{~cm}$ in a field lot. It is easy to make and maintain flat soil surface in smaller field lots. Also, the small field lots are better for water control. Therefore, normally the paddy fields are divided into small field lots by levees. But, in the case of upland farming which depends on rainwater such a tradition is not necessary. Therefore, wide fields are common in upland farming.

Due to these differences the tractors and their attached implements which were basically designed for upland farming are not suitable for lowland farm.

8) Sakai, J. 1984 (a)

9) Sakai, J. 1984 (b) 
ing unless they are properly modified and improved. Having realized this fact, the Japanese farmers and agricultural engineers took immediate steps to modify and to improve the imported tractors and implements. At the beginning of the introductory stage, in 1920-21, 12 units of hand tractors equipped with rotary tillers ("Simar" in brand name) were imported from Switzerland. These tractors were found to be ineffective in cultivating paddy fields due to insufficient trafficability of wheel mechanism and poor adaptability of the tillage device. Therefore, following the internal mechanism of these imported tractors, some Japanese firms made effort to manufacture hand tractors which were suitable for paddy fields. As a result, in 1926, the first model of locally made rotary power tiller, "Itano" in brand name, and then in 1932 "Fuji" power tiller appeared. However, these machines were also effective mainly on upland soils ${ }^{10)}$. Owing to the further effort made by Japanese engineers to produce machines and implements which were more suitable for paddy fields, in 1940 Japanese rotary blades were invented by Kumaichi Honda and Rinsaku Satoh. Also, the tractor was improved by attaching rotary blades and rubber tyres in 1953. This machine started to be used for puddling the paddy fields.

In 1952, a motor tiller made in the USA, "Merry Tiller" in brand name was imported. This machine was equipped with simple rotors, instead of the wheels, on the drive shafts and driven with 2.5 horse power gasoline engine. Some Japanese engineers made attempts to make this hand tractor suitable to the paddy fields by attaching the traditional Japanese plough to the imported hand tractor. The western ploughs were found to be not suitable for hand tractors because "the plough-bottom of the western plough has a principle of being used horizontally as a rule and its beam has to be vertical all the time, while the hand tractor always has to incline as shown in Figure 2 (Sakai, 1984 (a), p. 9). But, the Japanese plough, which had already been improved, had special adjustable mechanisms so that it could successfully be used with the hand tractor.

At this point it is worthwhile to observe the evolutionary process of the Japanese plough because it will further explain how the Japanese farmers modified and improved the imported implements. At the initial stage of the "Suki culture" (usage of animal drawn ploughs for ploughing the paddy fields) Japanese adopted the long sole plough (Figure 3) from Northern China. This long sole plough came into practice in Japan through Korea. This type of plough was stable due to the length of its plough sole, and therefore its handling was easier. Also, the long sole was effective to form the hard pan under the top soils. But its disadvantage was the greater friction which it had at the bottom. During the period of 5-7 centuries, Japanese adopted the non-sole plough (Figure 4) which was appeared in Southern Korea. Due to the absence of a sole, it had the advantage in less friction between the sole and furrow bottom but it was unstable. Following the technical principles of the both types of these ploughs, Japanese engineers invented the short sole

10) Sakai, J. 1984 (a) 

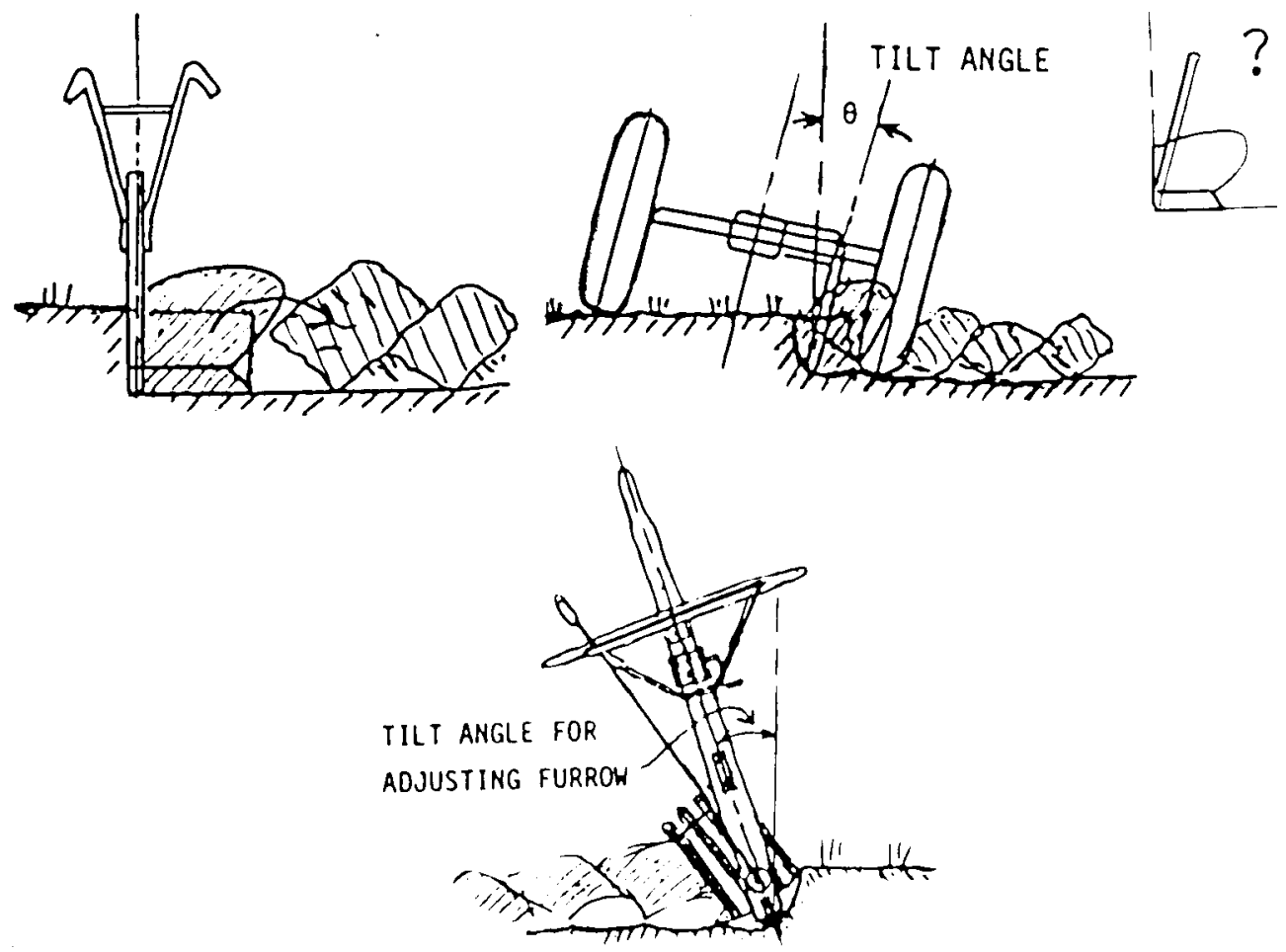

Fig. 2. Western Plough Beam is Vertical but Ploughing Hand Tractor inclines.

Source: Sakai, J. 1984 (a)



Fig. 3. Long-sole Plough.

Source: Hirobe, Tatsuzo 1913 Noguron (Agricultural Tools). Seibido, Tokyo 


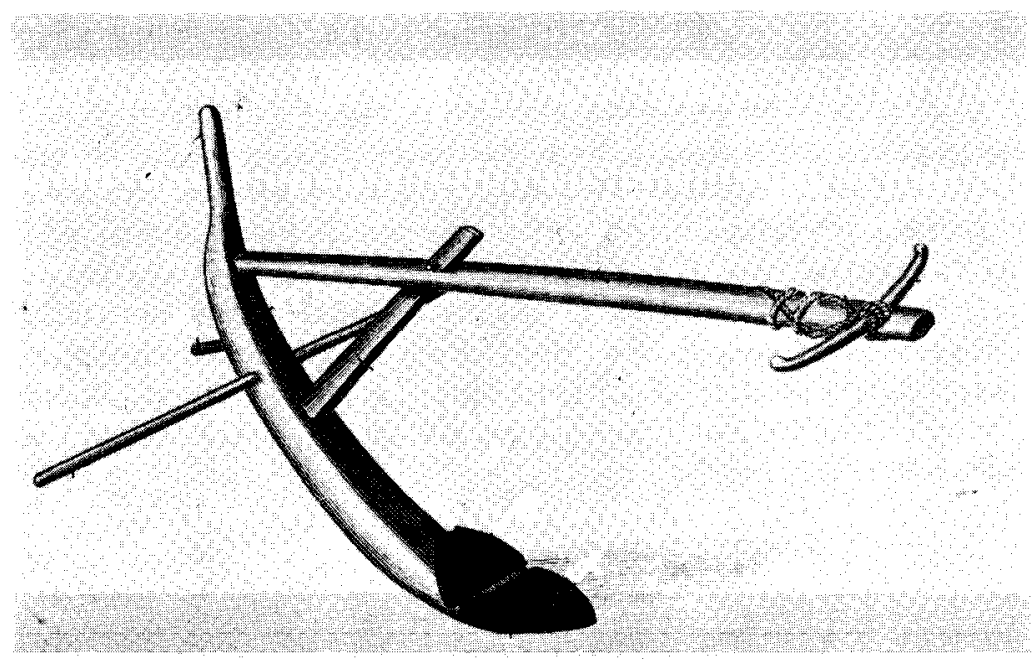

Fig. 4. Non-sole Plough

Source: Hirobe, Tatsuzo 1913 Noguron (Agricultural Tools). Seibido, Tokyo

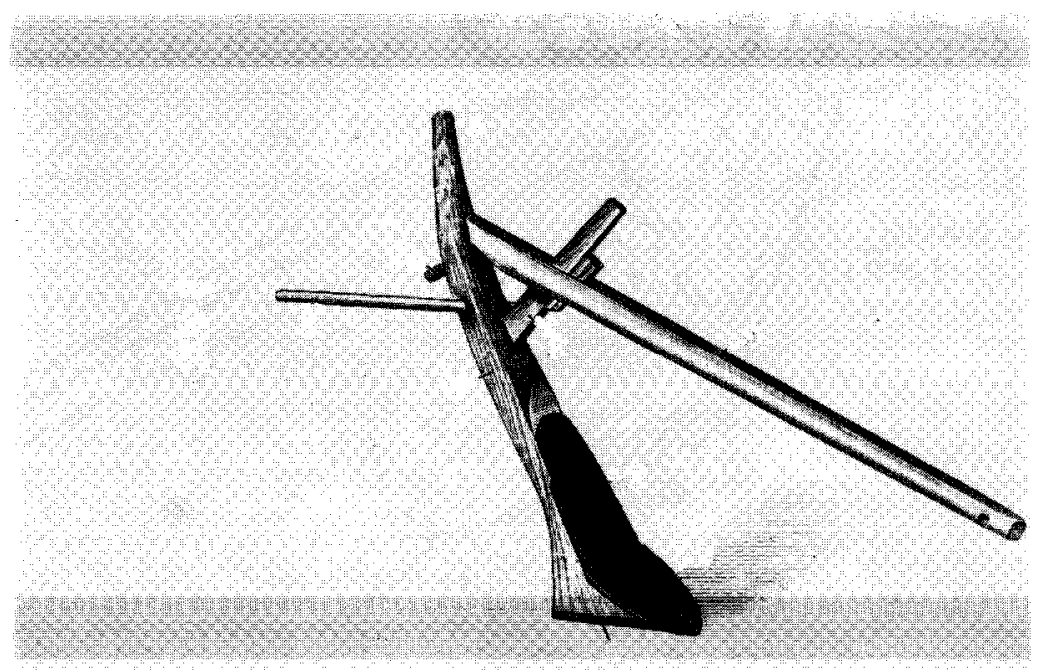

Fig. 5. Short-sole Plough.

Source: Hirobe, Tatsuzo 1913 Noguron (Agricultural Tools). Seibido, Tokyo

plough which had medium structure between long sole and non-sole ploughs (Figure 5). In contrast to the non-sole plough, it was stable and easy to keep in the proper position, and it was effective to form the hard pan due to the presence of a sole. On the other hand, in contrast to the long sole plough, due to shortness of the sole, it generated only a little friction. In this way, by combining the technical principles of the imported ploughs, 
Japanese engineers invented their own plough which was more effective and suitable for paddy fields.

Up to this stage, the Japanese plough remained as a fixed plough. Since 1900 s, some Japanese agricultural engineers took further steps to improve its efficiency by adding a number of adjustable mechanisms. In 1902, Suejiro Ohtsu in Kyushu, developed two adjustable mechanisms which enabled the ploughman to control the depth and width of ploughing. Further improvements made by Genzo Matsuyama in 1899/1900, enabled the controlling of the inverting direction of plough for the furrow by giving an optimum angle to the turn-wrest lever of the plough handle. This turn-wrest plough became the most standard and popular animal plough in the last stage of the animalpowered farming (Figure 6).

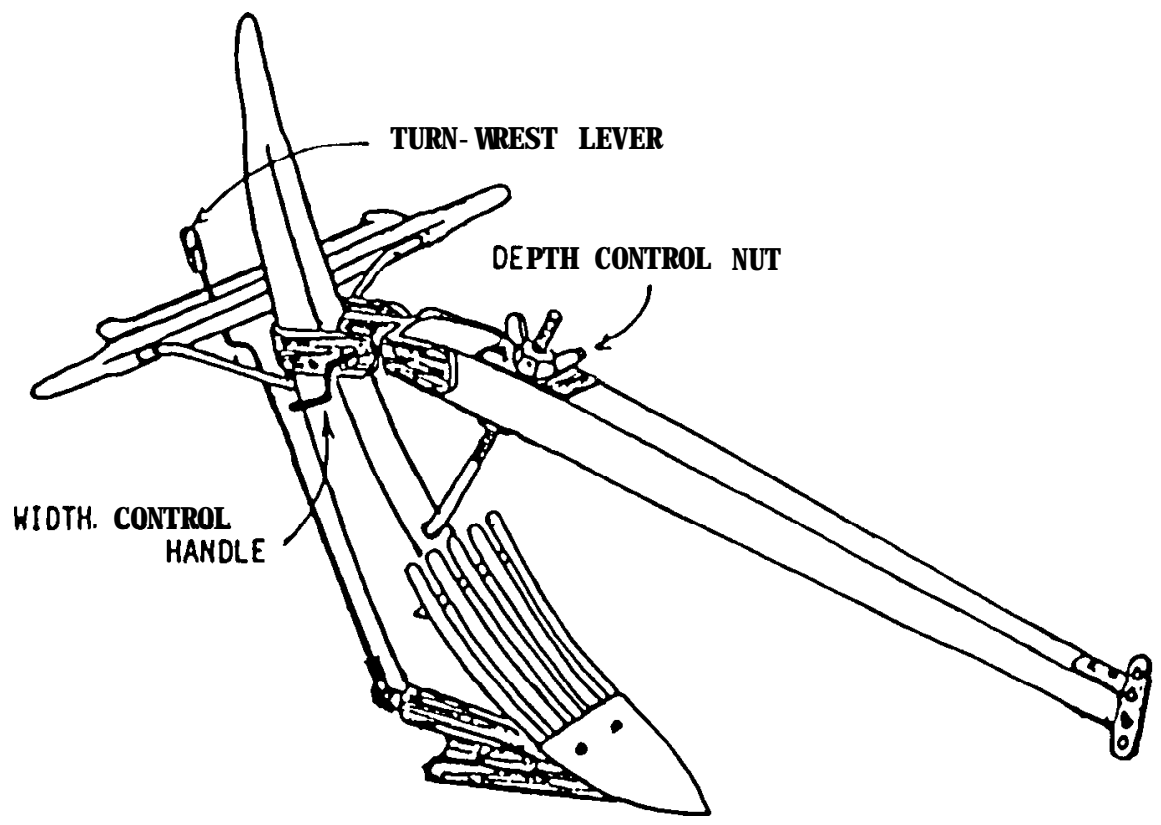

Fig. 6. Japanese Turn-wrest Plough.

Source: Sakai, J. 1984 (a)

In this way, Japanese engineers modified and improved the imported tractors and ploughs separately, and at last they combined the two items together. By doing so, they invented the Japanese traction-type power tiller. This traction type power tiller attached with the improved traditional plough enabled the farmer to adopt the sophisticated mechanical power without changing their traditional farming system.

Transition from animal draught power to mechanical power (small hand tractors) could be done smoothly without any radical change in farm structure, ploughing method, ploughing depth and cost, due to the usage of the improved traditional plough in combination with the hand tractor because of 
the following reasons.

a. The traditional plough enabled the hand tractor to plough more efficiently, keeping the plough depth at the same traditional level. In other words it enabled the hand tractor to plough without breaking the hard pan; instead its sole was effective to perform the hard pan.

b. The traditional plough (due to its adjustable mechanisms which enabled the operator to change the sending direction of furrow slices) was a kind of reversible plough which could be used for the method of continuous return ploughing. Due to this adjustable mechanism, when the operator returns from one end to the other end of the field lot, he could adjust the plough so that the furrow slices are sent in the same direction, as it is illustrated in Figure 7 (a). By this method since the furrow slices fall one upon one in the same direction, it finally performs a more or less perfectly flat field surface which is ideal for paddy cultivation. But other alternative methods, i. e. continuous ploughing and return ploughing, which are popular in upland farming in Europe, do not perform such an ideal flat field surface. Furthermore, unlike return ploughing, this method (continuous return ploughing) economizes the time because the former method needs to spend long running time on head land as shown in Figure 7(b). It is said that the running time needs to spend about $8 \%$ of total ploughing time. In this way, the usage of the improved traditional plough in combination with the hand tractor made it possible to continue the traditional method of continuous return ploughing more efficiently.

c. The price of the hand tractor attached with the traditional plough was almost same as the price of a cattle. Therefore, farmers could easily replace cattle with hand tractors. For example, retail price of this traction-type hand tractor was only $¥ 85,000$ (US \$236), which was less than a half to one third of that of the rotary power tiller, and almost the same price as a cattle in $1953^{11}$.

d. Thus, the transition from animal draught power to mechanical power did not change either the ploughing method or the value of the capital invested in power units. Therefore, mechanization became possible under the prevailing small paddy holdings with small field lots. These small hand tractors could be used in small field lots without troubles.

In this way, modifications and improvement of the imported tractors and implements appear to have considerably contributed to the quick and smooth transition from animal-powered cultivation to mechanical-powered cultivation in Japan. Sri Lanka neither modified nor improved the imported tractors and

11) Sakai, J. 1984 (a) 
implements. Also, Sri Lanka did not improve her traditional plough; instead the traditional plough was replaced by the imported tillage equipments attached with the imported tractors. For example, the tractors imported from Great Britain, at the introductory stage of mechanization, were equipped with disc-gang ploughs, disc harrows and tine tillers which were basically designed for upland farming.

Consequences of the Sri Lanka's approach to mechanization have become apparent in recent years. Some policy makers and farmers appear to have understood the mistakes they have done at the introductory stage. According to them the consequences of the utilization of large riding tractors attached with imported implements on local paddy fields have given rise to serious problems. For instance, the Farm Machinery Designs and Testing Unit of the Department of Agriculture recently stated that "the tractors with tine

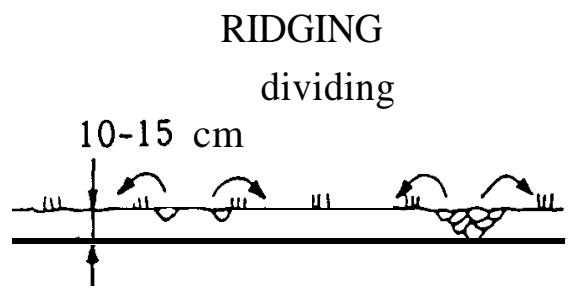

\section{FLAT PLOUGHING}

by continuous return ploughing

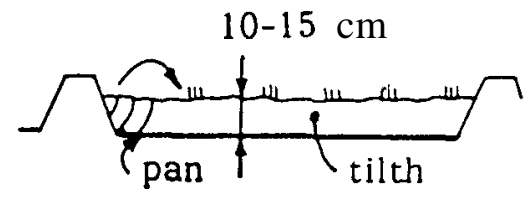

gathering
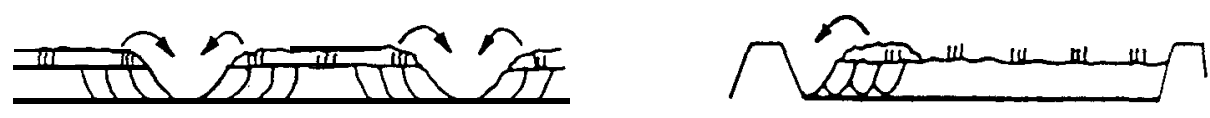

groove making
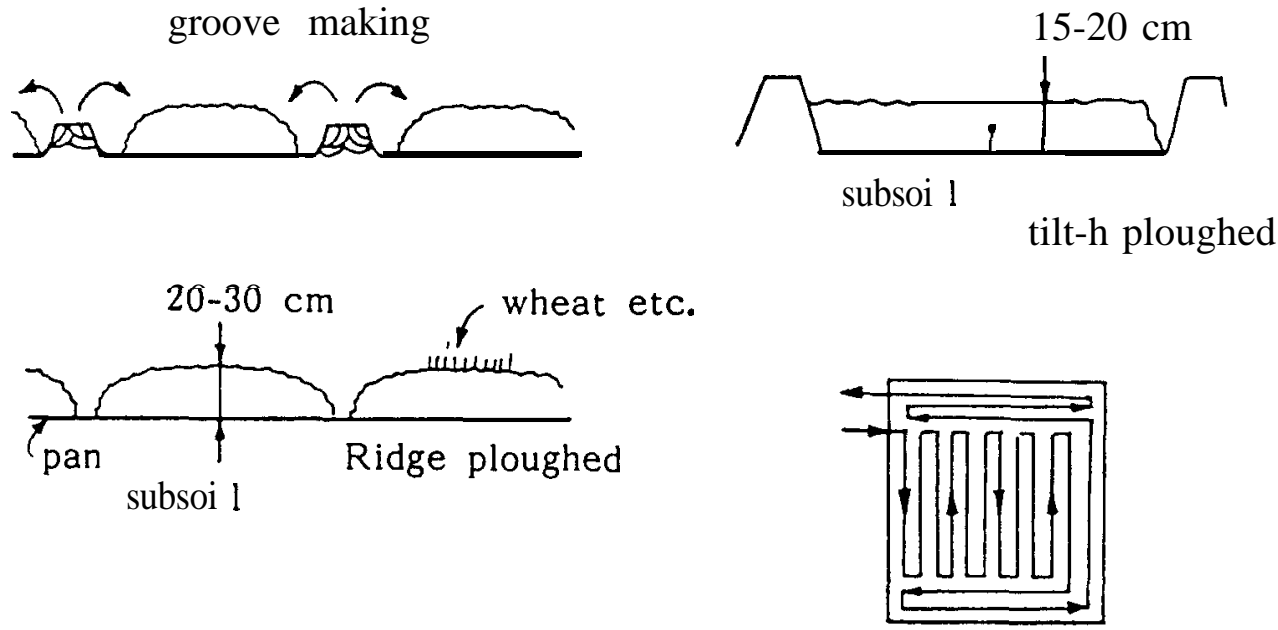

(a) 


\section{RETURN PLOUGHING}
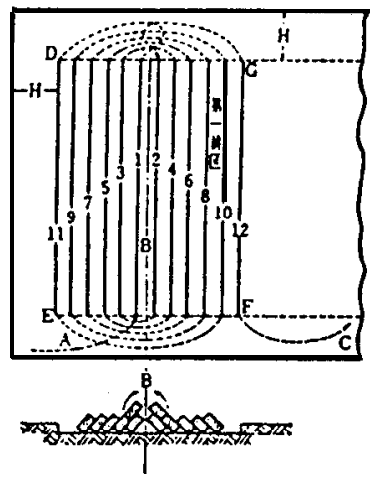

gathering

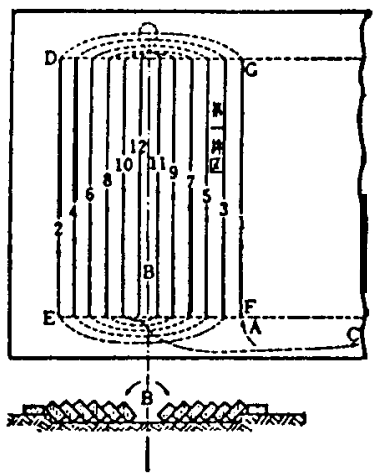

casting

\section{CONTINUOUS PLOUGHING}

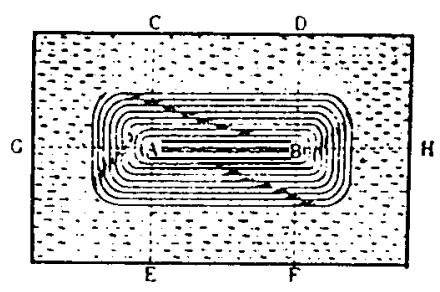

toward center

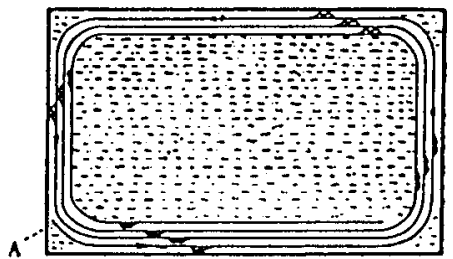

outward center

(b)

Fig. 7. General Ploughing Methods in Europe and Japan.

(a) Europe

(b) Japan

Source: Sakai, J. 1984 (b)

cultivators have literally replaced the animals with country plough and used under field conditions developed for traditional animal power operation in wet paddy fields. This pattern of tractorization had continued for the two decades resulting in damaged hard pan below root zone, loss of irrigation water, and making the paddy fields boggy" (Pillainayagam, 1982, p. 2). Expressing a similar opinion, a leading farmer in the dry zone states that "the tractor is much too heavy for the paddy field. Wherever it passes it breaks through the gley (hard pan) and water penetrates into the subsoils. So, if one uses a tractor one requires very much more water and this especially today is unlikely to be available. Also, it stirs up the soil. The light organic matter comes to the surface and it is lost to the flood water. So its use leads to reduced fertility" (Goldsmith, 1982, p. 214). Due to the destruction 
of the hard pan which used to support the draught animals and men working upon it, sinkage problem has become noticeable. Consequently, now it is difficult for farmers to return to the traditional animal-powered method even if other circumstances are favourable for such a transfer.

Japan successfully avoided this kind of problems at the introductory stage of the farm mechanization. She modified the imported machines so as to be suitable to the conditions in local paddy farming whereas Sri Lanka adopted imported tractors as they were. In Japan, the tractors replaced only draught animals not the traditional plough whereas in Sri Lanka tractors replaced draught animals and traditional plough both.

Therefore, if Sri Lanka is to continue the mechanization with imported tractors and implements, she should take necessary steps to modify them so as to fit to the local conditions. Also, it is necessary to improve traditional implements and to encourage local manufacture of farm machines.

\section{Land improvement}

When farm machines are used on the field, the machine is operated between skill of the operator are not adequately improved so as to fit to the machine, the maximum work output of the machine cannot be gained. In Japan, land improvement schemes promoted the quality of paddy fields and facilitated the achievement of maximum efficiency of farm machines used for various farm operations whereas in Sri Lanka farm machines are used on non-improved paddy fields causing various problems which hamper the further promotion of mechanization. This section is intended to point out how the land improvement schemes facilitated the mechanization of paddy cultivation in Japan; what are the problems faced by the paddy land mechanization in Sri Lanka due to the introduction of farm machines to the non-improved traditionalstyled paddy fields, and what are the lessons that Sri Lanka can learn from Japan's experience in order to solve these problems.

In Japan where cultivable land is scarce, improvement of the quality of the available cultivable land is very important. In feudal Japan, land improvement was undertaken by landlords. After the land reform in which the land ownership transferred from landlords to farmers, due to the individual farmers' inability to finance the expensive land improvement projects, central and prefectural governments both had to provide a considerable share of the investment. Under the land improvement projects, measures have been taken to promote irrigation, drainage, the size of operational holdings, and size of field lots and farm roads. At the initial stage when animal draught power was the main source of farm power, land improvement was undertaken to make the quality of land fit to the animal draught power based field operations. Therefore, size of field lots, bearing capacity of paddy soils and farm roads were improved so as to facilitate the use of animal draught power. When the transition from animal draught power to mechanical power took place the quality of field conditions had to be improved to the standard in which farm machines could be operated efficiently (Table 1). 
Table 1. Historical Change in Farm Land Improvement Standards.

\begin{tabular}{|c|c|c|c|c|c|}
\hline & Before 1907 & 1907-1954 & 1955-1964 & $1965-1974$ & After 1975 \\
\hline $\begin{array}{l}\text { (Technical } \\
\text { condition) }\end{array}$ & $\begin{array}{l}\text { Mainly manual } \\
\text { cultivation }\end{array}$ & $\begin{array}{l}\text { Cultivation by } \\
\text { cattleand } \\
\text { horse }\end{array}$ & $\begin{array}{l}\text { Small machi- } \\
\text { nery } \\
\text { introduced }\end{array}$ & $\begin{array}{l}\text { Medium-sized } \\
\text { machinery } \\
\text { introduced }\end{array}$ & $\begin{array}{l}\text { Integrated } \\
\text { system of me- } \\
\text { dium-and la- } \\
\text { rge sized ma- } \\
\text { chinery intro- } \\
\text { duced }\end{array}$ \\
\hline \multicolumn{6}{|l|}{$\begin{array}{l}\text { (Improvement } \\
\text { standards of } \\
\text { paddy fields) }\end{array}$} \\
\hline Size of plots & $\begin{array}{l}\text { Irregular, } \\
\text { small plots }\end{array}$ & $\begin{array}{l}\text { Uniform plots } \\
\text { of } 8-10 \text { ares }\end{array}$ & Same as left & $\begin{array}{l}\text { Uniform plots } \\
\text { of } 20-30 \text { ares }\end{array}$ & $\begin{array}{l}\text { Plots for rice } \\
\text { only : } 30-60 \\
\text { ares per plot, } \\
\text { Plots both for } \\
\text { rice and other } \\
\text { crops : } 20-30 \\
\text { ares per plot }\end{array}$ \\
\hline Irrigation & $\begin{array}{l}\text { Irrigation } \\
\text { provided to } \\
\text { meet about } \\
1 / 7 \text { probability } \\
\text { year }\end{array}$ & Same as left & $\begin{array}{l}\text { Irrigation } \\
\text { reinforced } \\
\text { (1/10 proba- } \\
\text { bility year) }\end{array}$ & $\begin{array}{l}\text { Irrigation and } \\
\text { drainage se- } \\
\text { parated(plot- } \\
\text { by-plot water } \\
\text { management } \\
\text { made } \\
\text { possible), } \\
\text { Lining of chan- } \\
\text { nels provided }\end{array}$ & $\begin{array}{l}\text { Pipelines intro- } \\
\text { duced in some } \\
\text { areas, water } \\
\text { management } \\
\text { automatized }\end{array}$ \\
\hline Drainage & None & Same as left & $\begin{array}{l}\text { At } 1 / 10 \text { proba- } \\
\text { bility year } \\
\text { the allowable } \\
\text { depth of sta- } \\
\text { nding water } \\
\text { caused by daily } \\
\text { rainfall and } \\
\text { daily drainage } \\
\text { kept } 30 \mathrm{~cm} \text { or } \\
\text { less (drainage } \\
\text { needed mai- } \\
\text { nly to keep } \\
\text { the endura- } \\
\text { nce of soil) }\end{array}$ & Same as left & $\begin{array}{l}\text { Drainage capa- } \\
\text { city needed } \\
\text { for multipur- } \\
\text { pose fields } \\
\text { ensured, } \\
\text { Lining provided } \\
\text { to drainage } \\
\text { channels }\end{array}$ \\
\hline Farm roads & $\begin{array}{l}\text { Only trunk } \\
\text { roads }(3-4 \mathrm{~m} \\
\text { wide) } \\
\text { provided }\end{array}$ & $\begin{array}{l}\text { Roads in fie- } \\
\text { lds (1-2 m } \\
\text { wide) pro- } \\
\text { vided in } \\
\text { some areas }\end{array}$ & $\begin{array}{l}\text { Roads in fields } \\
\text { constructed } \\
\text { to reach } \\
\text { each plot }\end{array}$ & $\begin{array}{l}\text { Trunk roads: } \\
(6-7 \mathrm{~m} \text { wide } \\
\text { and paved), } \\
\text { Roads in fiel- } \\
\text { ds }: 3-4 \mathrm{~m} \text { wide }\end{array}$ & $\begin{array}{l}\text { Some roads in } \\
\text { fields paved }\end{array}$ \\
\hline $\begin{array}{l}\text { (Improvement } \\
\text { standards of } \\
\text { upland fields) } \\
\text { Size of plots }\end{array}$ & None & Same as left & Same as left & $\begin{array}{l}\text { Land readju- } \\
\text { sted and } \\
\text { slopes redu- } \\
\text { ced in some } \\
\text { areas (in re- } \\
\text { sponse to } \\
\text { mechanized } \\
\text { cultivation) }\end{array}$ & $\begin{array}{l}\text { Land readjust- } \\
\text { ment and } \\
\text { slopes of fiel- } \\
\text { ds made for } \\
\text { all necessary } \\
\text { fields }\end{array}$ \\
\hline Irrigation & None & Same as left & $\begin{array}{l}\text { Irrigation of } \\
\text { upland fie- } \\
\text { lds of vege- } \\
\text { tables, etc. } \\
\text { introduced } \\
\text { in some } \\
\text { areas }\end{array}$ & $\begin{array}{l}\text { Upland } \\
\text { irrigation } \\
\text { expanded }\end{array}$ & $\begin{array}{l}\text { Water manage- } \\
\text { ment automa- } \\
\text { tized }\end{array}$ \\
\hline
\end{tabular}




\begin{tabular}{|c|c|c|c|c|c|}
\hline & Before 1907 & $1907-1954$ & $1955-1964$ & $1965-1974$ & After 1975 \\
\hline Drainage & None & Same as left & $\begin{array}{l}\text { Drainage pro- } \\
\text { vided in some } \\
\text { areas } \\
\text { (mainly as a } \\
\text { means of } \\
\text { preventing } \\
\text { erosion of } \\
\text { farm land) }\end{array}$ & $\begin{array}{l}\text { Drainage } \\
\text { channels } \\
\text { providded, } \\
\text { Underground } \\
\text { drainage } \\
\text { reinforced }\end{array}$ & Same as left \\
\hline Farm roads & $\begin{array}{l}\text { Only trunk } \\
\text { roads }(3-4 \\
\text { m wide }) \\
\text { provided }\end{array}$ & Same as left & $\begin{array}{l}\text { Roads in fields } \\
\text { (1-2m wide) } \\
\text { provided in } \\
\text { some areas }\end{array}$ & $\begin{array}{l}\text { Trunk roads : } \\
6-7 \mathrm{~m} \text { wide } \\
\text { and paved, } \\
\text { Roads in fie- } \\
\text { lds: } 3-4 \mathrm{~m} \\
\text { wide }\end{array}$ & $\begin{array}{l}\text { Roads in fields } \\
\text { extended, } \\
\text { Roads on slo- } \\
\text { pes paved }\end{array}$ \\
\hline
\end{tabular}

Sourse: Inoue, Y. 1984 Long Term Plan for Water Resource Development for Agriculture Farming Japan 18 (1) : 23-27

Field operations pertaining to land preparation i.e. ploughing, harrowing, and levelling take place within the field lots. Therefore, the size and shape of field lots are crucial in determining the efficiency of machines used for these operations. Frequent stopping, for instance in order to change direction or move from one field lot to another, interrupts the operation and causes a reduction in overall efficiency. Therefore, field lots should be enlarged enough to keep the number of turnings and field changes to the minimum level. The operation efficiency of machines generally becomes higher in proportion to the size of field lots and the ratio of the long side to the short side of field lots. As it is illustrated in Figure 8, operation efficiency of ro-

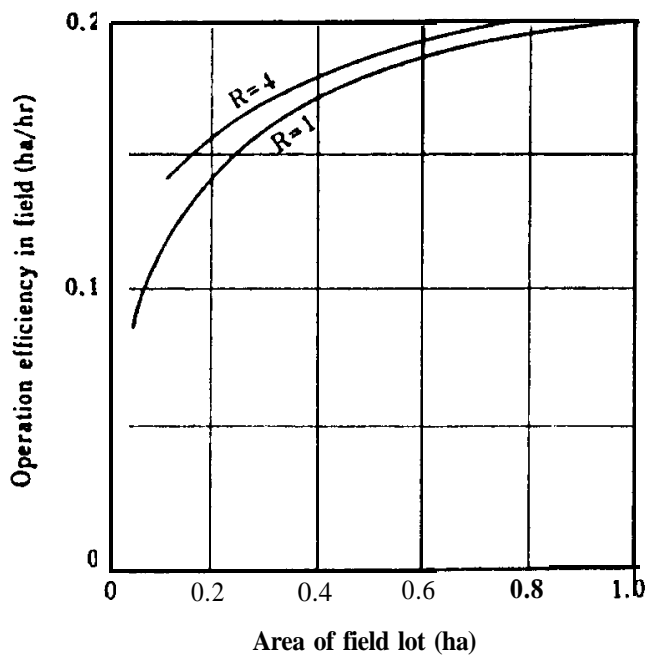

Fig. 8. Relation of Field Lot Area to Operation Efficiency in Field. Note: R, Ratio of long side to short side Source: Taniyama, S. 1975 


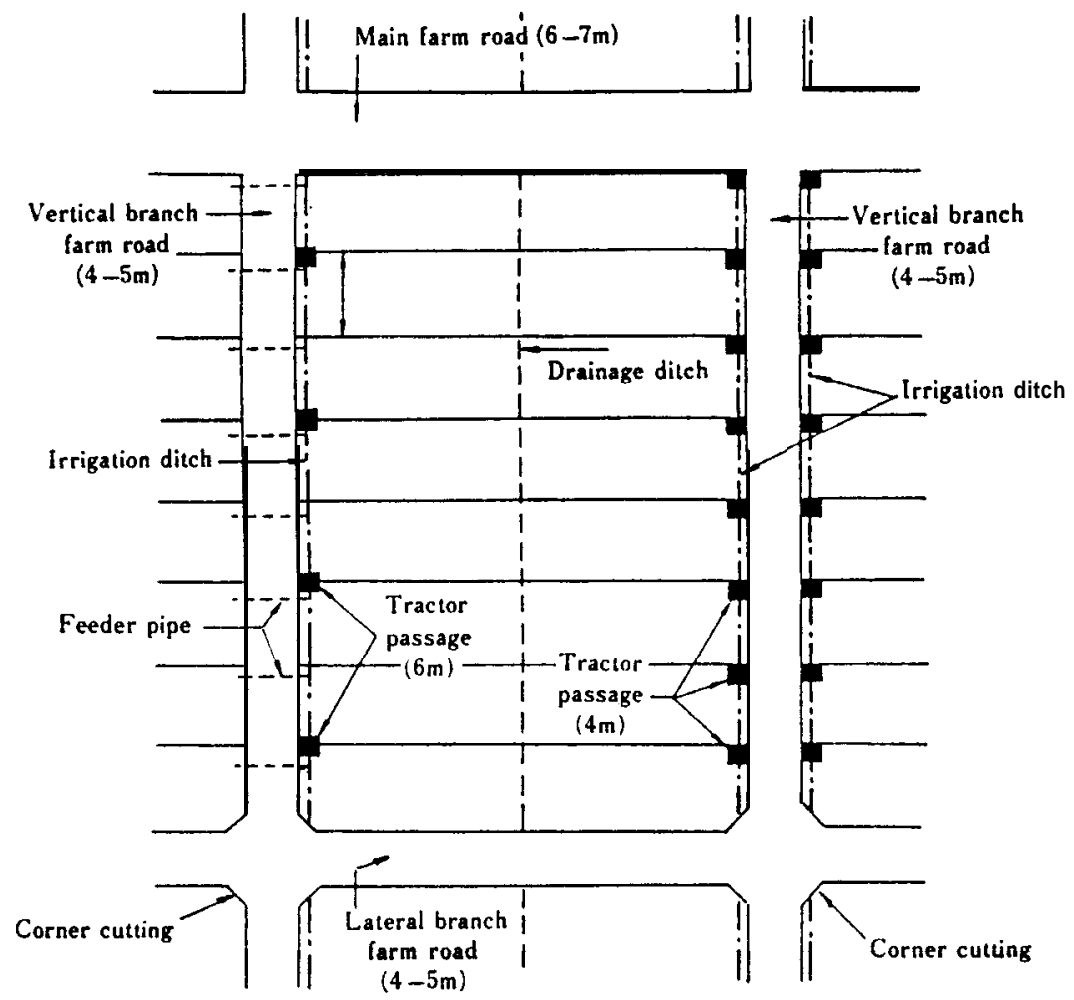

Fig. 9. Field Surface of Improved Paddy Fields in Japan.

Source: Taniyama, S. 1975

tary cultivation with $30-40$ ps wheel tractor increases a little when the size of field lots exceeds 0.3 ha in extent but it remarkably decreases when the size of field lot becomes below that level. As the long side to short side ratio increases, the efficiency increases. However, considering convenience of machine turning, length of long side and short side has been standardized as $100 \times 30$ meters.

Each field lot has to be provided with farm roads suitable for farm machines in order to promote the accessibility. Therefore, the layout of farm roads has to be readjusted so as to facilitate bringing farm machines to each field lot without causing damage to machines, to levees and to irrigation channels. As it is illustrated in Figure 9 the layout of farm roads has been readjusted and the width and height of farm roads have been standardized as follows ${ }^{12}$.

Width of farm roads

Main farm roads: 6-7 meters (which enables two trucks to pass each other)

12) Taniyama, S. 1975 
Branch farm roads: 4-5 meters (which enables a combined harvester and thresher to pass each other)

Height of farm roads

Main farm roads: $50 \mathrm{~cm}$ (height from field surface)

Branch farm roads: $30 \mathrm{~cm}$ (height from field surface)

Besides, the bearing capacity of farm roads has been improved by paving with asphalt concrete of which thickness is about $5 \mathrm{~cm}$ for main roads, and with gravel or crushed stones for branch roads.

Though enlarged field lots facilitate the operation efficiency of machines it makes the drainage rather difficult. For example, the degree of land levelling becomes insufficient in large field lots, and rapid drainage of surface water becomes more difficult compared with that of usual small field lots. The resulting poor drainage obstructs the efficient operation of farm machines. The residual water remaining in field lots causes damage to the machines, and also the poor bearing capacity of ill-drained paddy soils increases the sinkage. Therefore, specific measures have to be taken to improve the drainage and to promote the bearing capacity of paddy soils so that heavy machines could be operated on the surface soil layers. Proper control over drainage is inevitable if the transplanting machines are to be used because, for example "for unwashed seedlings it is necessary to control irrigation and drainage that is, to make water level low in planting and high at the erection of seedlings" (Kisu, 1970, p. 141). The land improvement projects improved drainage, and promoted the farmers' control over the water level in field lots by providing separate irrigation and drainage channels to each lot (Figure 9) and by taking specific measures to improve the subsurface drainage too. In this way, improved drainage under land improvement projects facilitated the mechanization. For example, paddy fields in the downstream basin of large rivers (e.g. Kameda region in Niigata Prefecture and Sakai plains in Fukui Prefecture) were so wet that farmers were waist-deep in water and mud in these fields ${ }^{13)}$. In these regions therefore, fields had to be improved prior to the introduction of power tillers. First of all, large scale drainage facilities were constructed for the purpose of local drainage, followed by improvement of trunk and branched water channels; irrigation and drainage channels were separated to allow a more smooth drainage. At the same time, efforts were made to enlarge the plots of paddy fields. "In this case, land improvement meant reformation of wet paddy fields (shitsuden) into welldrained (kanden) ones, enlargement of plots and betterment of irrigation and drainage channels. In these regions, even power tillers, the relatively small machines, would not have been spread fully if this effort in land improvement had not been made" (Kawashima, 1984, p. 51). Further evidence can be drawn from the Agano-gawa Irrigation and Drainage Scheme in the Kamedago district in Niigata prefecture. In this area "before the implementation of the land improvement schemes no distinction was made between the process of tillage, harrowing and levelling, and these were all carried out by hand

13) Kawashima, T. 1984 
tractor simultaneously right before transplanting took place, except in areas of uneven land. However, after irrigation and drainage facilities had been improved by the land improvement schemes a distinction was observed between the tillage, harrowing and levelling process and in certain instances deep tillage was also practised. As the soil of the rice fields became firmer as a result of improved drainage there was a rapid spread of the use of power cultivators" (Tsuchiya, 1976, p. 206-207). Furthermore, under some land improvement schemes, for instance in Kahoku project, underground pipe lines were installed and it facilitated to bring the farm tractors into and out of the field. Under the land improvement projects, the surface of paddy fields was perfectly levelled in order to facilitate the smooth operation of farm machines. The rough and rolling nature coupled with residual water in paddy fields which were not properly levelled obstructed the efficient operation of farm machines. Land improvement projects levelled the surface of field lots keeping the degree of levelling within the limit of $\pm 5 \mathrm{~cm}$. Therefore, operation of farm machines on paddy fields under Kahoku project, in the lower part of the Tone river has considerably facilitated the mechanization in this area ${ }^{14)}$. During the project construction, the lowland was filled with soil from the dredging of the Tone river and the land was levelled off. The benefitted area included the lowland area where the rice was previously grown on the ridge to protect it from flood damage and in this area it was not possible to use the farm machinery because the land was too rough and rolling. But the levelling which took place under the land improvement made the mechanization possible.

Before the land improvement, one farmer had many small plots scattered here and there. This impeded the mechanization by creating small field plots and by increasing the time that has to be taken for travelling from one plot to another. Grouping of scattered small plots into larger ones, therefore, undoubtedly facilitate the mechanization. For example, in the Okijima village (Kahoku project area) each farmer had from 1-17 plots that were often located in different places. After farm land has been consolidated, farmers owned a relatively large farm size for each plot, about 0.5 ha per plot on the average ${ }^{15}$.

In this way, land improvement projects facilitated the mechanization of paddy farming in Japan. Further evidences for this, have been provided by Tsuchiya (1976). He points out the similarity between the regional variation of the land improvement and the regional variation of the spread of power tillers. Table 2 shows a big difference among regions in the number of power tillers used. In the high yield rice-producing regions, such as Tohoku (NorthEastern) and Hokuriku (North-Western) the number of units was 61.3 per 100 families in 1967, but in southern areas like Kyushu it was only 31.4. Investment in land improvement (agricultural social investment) also showed a similar regional variation. Table 3 shows the estimated social capital stock for each

14) Nagata, K. 1973

15) Nagata, K. 1973 
Table 2. Number of Power Tillers per 100 Farms.

\begin{tabular}{lcr}
\multicolumn{1}{c}{ Kind of Districs } & $\begin{array}{c}\text { Number of } \begin{array}{c}\text { Tillers } \\
\text { in } \\
1967\end{array} \\
\text { in } 1960\end{array}$ & 56.0 \\
National average & 8.6 & 53.0 \\
Industrial districts & 9.6 & 61.3 \\
Districts surrounding big industries & 6.6 & 61.3 \\
Suburb districts of local industries & 12.1 & 56.4 \\
Agricultural districts & 9.1 & 58.3 \\
Districts with high rice yield & 7.5 & 31.4 \\
Districts producing commercial agricultural products & 6.6 & 2.1 \\
Districts with medium rice production & \\
Districts producing crops excluding rice & & 31.4 \\
Remote districts & &
\end{tabular}

Table 3. Amount of Social Capital Stock per Hectare of Cultivated Land (thousand yen, 1965 price).

\begin{tabular}{lccr}
\hline Region & $\mathbf{1 9 1 8 - 1 9 5 2}$ & 1963 & $\mathbf{1 9 7 2}$ \\
\cline { 2 - 3 } Tohoku & 272 & 478 & 589 \\
Kanto & 274 & 411 & 448 \\
Tokai & 285 & 797 & 1,248 \\
Hokuriku & 283 & 472 & 1,041 \\
Kinki & 175 & 322 & 746 \\
Chugoku & 143 & 331 & 622 \\
Shikoku & 203 & 421 & 636 \\
Kyushu & 230 & 392 & 558 \\
\hline
\end{tabular}

Source: Social capital stock for agriculture is calculated from data in Norin Gyogyo no Chiikibetsu Shihon Sutokku no Suikei Kekka (Estimation of Regional Capital Stock for Agriculture and Forestry), and cultivated land area from data in Norinsho Tokei Hyo, both by the Ministry of Agriculture and Forestry. Quoted from Tsuchiya (1976).

agricultural region, including two newly developed industrial regions, Tokai and Chugoku. The social investment is greater in advanced rice-producing regions, such as Tohoku (North-Eastern) and Hokuriku (North-Western), and less in southern regions like Kyushu. Likewise, it is Tohoku and Hokuriku that have seen the large introduction of power tillers. On account of this similarity he concludes that "the increase in social capital investment for land improvement precedes the expanded use of such power tillers. Once a land improvement project is carried out the drainage is better, rearrangement of the paddy fields makes each plot larger, and the introduction of machinery becomes easier" (Tsuchiya, 1976, p. 174).

By the way, the regional difference in agricultural social investment in Japan has resulted partly from the difference in climatic conditions. For example, in northern parts of Japan, the climatic condition is so severe that active agricultural social investment has been made on preferential basis to help 
poor farmers.

Land improvement becomes more significant in the case of large scale mechanization. After 1966, when the riding tractors, transplanters and combines began to play a dominant role in the mechanization, the size of field lots and farm roads, bearing capacity of paddy soils have become more crucial in determining the efficient utilization of these farm machines. As Keizo Tsuchiya rightly points out "in large-scale mechanization, land improvement scheme (including irrigation and drainage, etc.) is very essential. As improved drainage caused hardening of the earth, efficient ulilization of large scale mechanization can be promoted. Also, improvements are needed in the largesized plots and farm roads where large scale machines can be used" (Tsuchiya, 1976, p. 184). Further evidence in support of this opinion can be mentioned here. Due to the heavy fixed cost incurred in large scale mechanization, farmers tended to organize themselves into groups in order to reduce the heavy burden of investment. Land consolidation, which is considered here as a component of the land improvement, facilitated the joint ownership and utilization of farm machines. For example, as it was evident in Ohama town group farming in Shizuoka Prefecture, "farmers who had paddy fields in and out of the group farming district employed modern farming on one hand and old type agriculture on the other, and loss from the duplication of individual and group management such as the overlapping of capital investment became a big issue. So, the administration of community had to be directed to promote proper utilization of land by means of consolidation" (Hayakawa and Watanabe, 1970, p. 194). Concerning the case of Hosoe-Nakagawa 9th district which has undergone a highly mechanized group utilization of paddy rice "during the period of construction, from April, the meetings at a subcommunity level have been repeated on land exchange, and those meetings have arrived at the conclusion that land consolidation is most essential for an effective land use and effective operation of machinery such as tractors, combines, and paddy dryers" (Hayakawa and Watanabe, 1970, p. 194).

In Sri Lanka, although large scale tractors (HP 35-45) at first and power tillers, second were introduced into paddy fields, land improvement has not yet been implemented. Therefore, tractors and power tillers are operated on non-improved paddy fields. In consequence, mechanization of paddy land preparation is faced by problems arising from the ill-drainage, and poor bearing capacity of paddy soils, spersely located paddy plots, the small size and irregular shape of field lots, and poor access to fields.

Most of the paddy fields in the wet zonal coastal area are prone to frequent flooding. The main problem in the wet zonal paddy fields is water logging consequent on human failure to manage and maintain drainage channel. Due to the excess water remaining in field lots, tractors and power tillers cannot be properly operated. Concerning the power tillers, their maximum work output could be gained only if the operator can walk at the proper speed behind the machine. When power tillers are used on too wet soils, the operator is unable to walk at the proper speed, which result in reduced work output. Apart from this, if tractors are operated on ill-drained submerg- 
Table 4. Average Size of Field Lots of Paddy Fields in Two Traditional Villages in the Dry Zone of Sri Lanka.

\begin{tabular}{|c|c|}
\hline $\begin{array}{l}\text { Location } \\
\text { (1) }\end{array}$ & $\begin{array}{c}\text { Average size of } \\
\text { Field lots } \\
(2)\end{array}$ \\
\hline (A) Unagaswewa & 0.07 \\
\hline (B) Nallamudewa & 0.06 \\
\hline
\end{tabular}

ed paddy fields, water and mud will damage the machine. Therefore many tractor owners are unwilling to hire their tractors for tillage in submerged paddy fields. Some paddy fields in the wet zonal lower river valleys are associated with deep boggy soils (hal kuburu). On this type of paddy fields, due to the absence of a hard pan, only the hand labour can be used. Therefore, if the mechanization is to be introduced into this type of paddy fields, drainage system and the bearing capacity of paddy soils have to be improved.

The size and shape of field lots in the paddy fields in Sri Lanka still remain the same as they had been for centuries. They are too small and irregular when compared with the field lots in improved paddy fields in Japan (Table 4). Since the small field lots are better for efficient and easy water management, in view of the scarcity of water, farmers traditionaly divided their paddy plots into small field lots. When tractors are used in such a small and irregular field lots, work performance and the work output of machines both become poor. Unsuitability of the average size of field lots for mechanization was recognized in the very beginning of mechanization by the irrigation authority ${ }^{16)}$. A report by $\mathrm{FAO}$ advisers on farm mechanization in 1953 indicated up to 23 field lots per acre, prompting the ministry of land to declare that future colonization schemes would be laid out with only 4 field lots per acre. Yet the high density continued and was advanced by Brohier (1975) as the principal constraint to mechanization in major colonization schemes. In recent studies it has been observed that small field lots have substantially reduced the work output of tractors"'. These authors had observed that four-wheel tractor tilling irrigated field lots so small that the tractor has been forced to reverse the full length of the field lot to start a fresh traverse. Tractor ploughing is also often blamed for leaving unploughed strips and corners and breaking levees. All these disadvantages are considerably attributable to the small size of field lots.

In the paddy field in Sri Lanka each field lot has no access to farm roads. Farmers usually use levees and ditch banks as farm roads when they drive draught animals to field lots. This situation was almost the same in Japan before 19th century ${ }^{18)}$. After the construction of farm roads, providing easy

16) Taylor, S. G. 1945

17) Farrington, J. and F. Abeyratne 1982

18) Yukawa, K. 1975 
access to each field lot (see Figure 9), now machines can be driven to each field lot without causing damages to levees or irrinage (irrigation and drainage, proposed by prof. H. Fukuda through ICID, Varna, Bulgaria, 1972) channels. In Sri Lanka, due to the absence of suitable farm roads to each field lot, tractors have to be driven across the levees and irrinage channels, causing damages to them and to tractors too.

In traditional villages, almost every farmer has more than one paddy plot which are located in different places in the same paddy tract or in different paddy tracts. Under such a situation when they use farm machines, the machines have to be brough from one plot to another. Consequently, it increases the unproductive-running time. Consolidation of the scattered small paddy plots into larger ones is, therefore, very important to promote the mechanization as it was seen in Japan.

Now it is evident that the usage of tractors and power tillers on nonimproved paddy fields in Sri Lanka causes low work performance and reduced work output of machines. As it has been mentioned already, if the maximum efficiency of farm machines is to be gained, the condition of the field on which the machines are operated, has to be improved. In Japan, the land improvement schemes improved the field conditions so that the farm machines could be used efficiently, but in Sri Lanka, almost the same types of farm machines are used on non-improved paddy fields, causing various problems. Therefore, Japan's experience suggests that Sri Lanka needs land improvement schemes if the mechanization is to be promoted.

Concerning the dry zone of Sri Lanka where the paddy land preparation is heavily dependent on mechanical power, implementation of land improvement projects in order to facilitate the mechanization seems to be advisable. Unlike Japan, due to the high temperature prevailing throughout the year and the naturally dry soils on paddy fields, drainage is not so serious a problem. Therefore, the land improvement projects designed to consolidate the dispersed small paddy plots into large holdings and to enlarge and rectangularize the small irregular field lots and to provide farm roads are quite adequate to facilitate the mechanization. From here, attempts will be made to observe the feasibility of the implementation of such land improvement projects on the comparative basis with Japan's experience. Hence, the objectives to be achieved are as follows.

a. To identify the similarity between the paddy field condition in Japan prior to the implementation of land improvement projects executed under the Land Improvement Law of 1949, and the present paddy field conditions in the dry zone of Sri Lanka.

b. To point out the major socio-economic factors which would impede the implementation of such land improvement projects in Sri Lanka.

c. To identify possible solutions for these problems through Japan's experience. 


\section{(i) Consolidation of dispersed paddy plots}

For many hundreds of years the typical farm holdings in Japan and in Sri Lanka both have consisted of many scattered plots. While in Japan land improvement and consolidation projects gradually grouped the scattered small plots into large ones, in Sri Lanka, the scattered pattern still remains. The pattern of scattered farm plots existed in Japanese villages before the implementation of land improvement projects was quite similar to the existing pattern in Sri Lankan villages.

In Japanese villages in the 1940 s the average family holdings consisted of some 15 or 20 farm plots. The average plot was only about 500 sq. meters, and the distance between two plots belonging to one farmer was several kilometers ${ }^{19}$. A survey conducted in three villages such as Suye, Yokogoshi

\section{NUMBER AND LOCATION \\ OF 70 PLOTS OPERATED BY SEVEN FARMERS \\ IN SUYE, DECEMBER 1948}

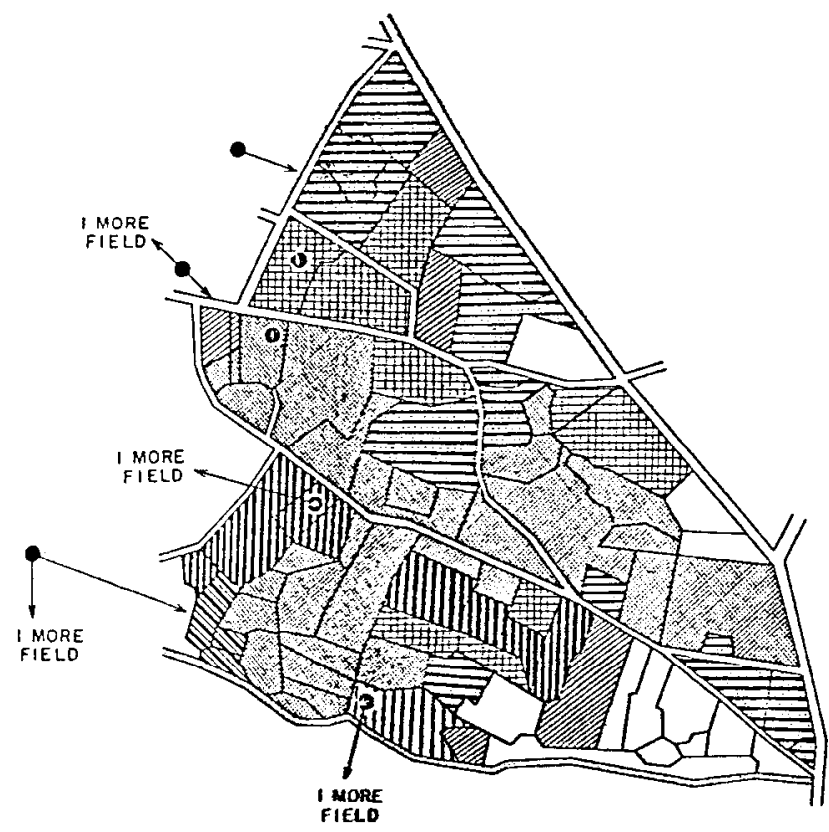

LEGEND

0 HOUSE SITE

$=\mathrm{ROAD}$

$=$ IRRIGATION DITCH

(a)

19) Williamson, M. B. 1951 
NUMBER AND LOCATION OF 35 PLOTS OPERATED BY SEVEN FARMERS IN YOKOGOSHI, DECEMBER 1948

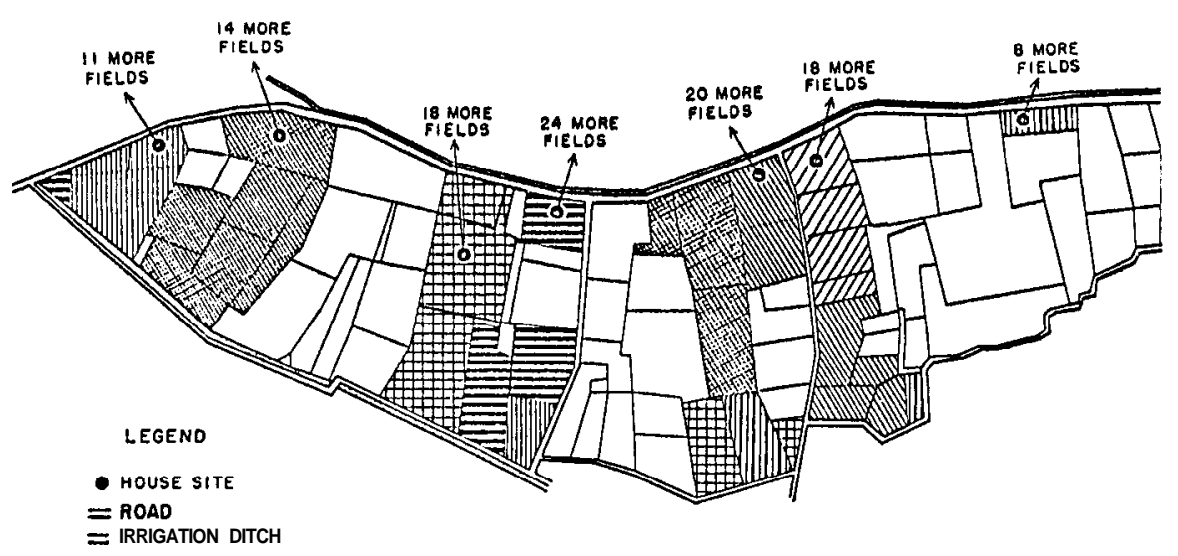

(b)

LOCATION OF 19 PLOTS OPERATED

BY ONE FARMER IN KARAKO, DECEMBER 1948

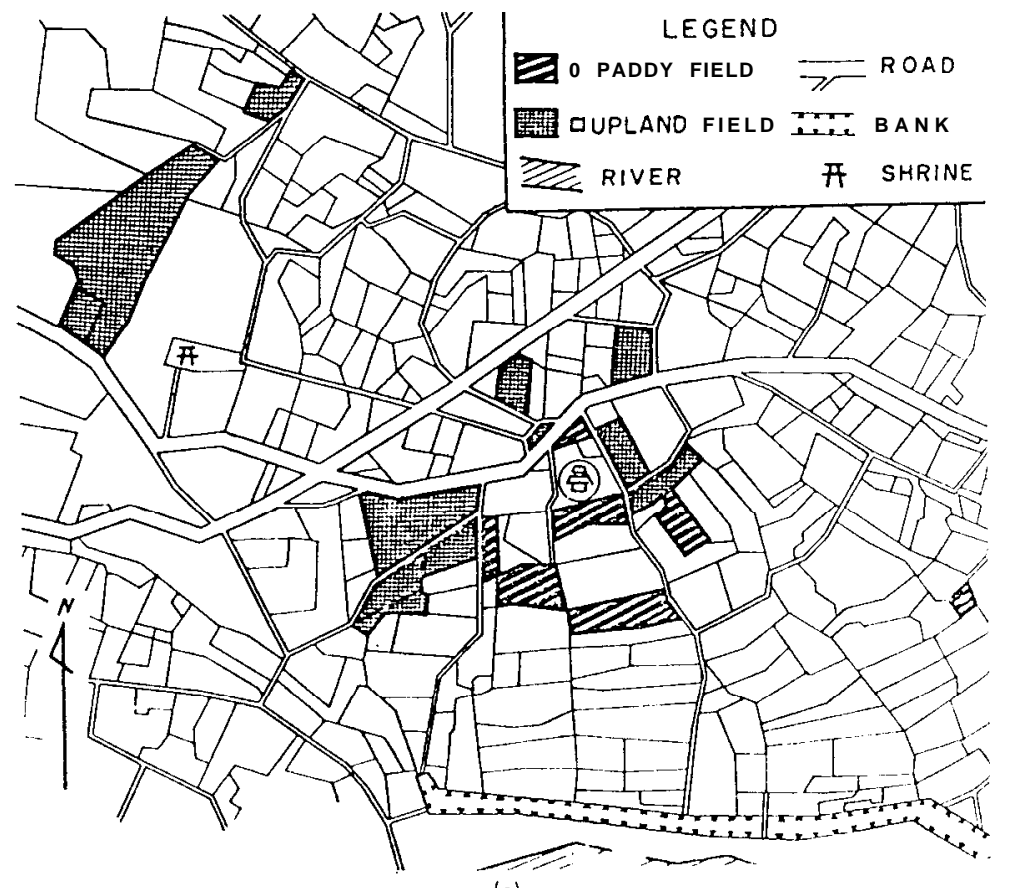

(c)

Fig; 10. Scattered Field Plots in Three Villages in Old Japan.
(a) Suye
(b) Yokogoshi
(c) Karako
Source: Raper, A. F. 1950 
and Karako in 1940s provides evidence for the scattered patterns of holdings ${ }^{20)}$. Figure 10 shows the location of 70 plots of seven farmers in Suye, 35 plots of seven farmers in Yokogoshi, and 19 plots of one farmer in Karako. The farmers in Suye had an average of 10 plots inside the selected locality and one-half a plot outside that area; in Yokogoshi, the farmers had an average of five plots inside and 16 outside the area. The farmers in karako had seven paddy and 12 upland plots which were widely scattered. The fields were most numerous and scattered in the areas that had been farmed longest and where rice cultivation was most intensive; fields were least numerous and least scattered in the newly settled areas in Hokkaido and Northern Honshu. In Sri Lanka too according to a survey conducted in a number of dry zonal villages ${ }^{21}$ an average farmer has 1.7-3.5 field plots and the average size of a plot ranges from 0.2 acres to 0.4 acres. In some villages the ownership of field plots ranges from 1-10 (Table 5). Same as it was seen in Japan the number of field plots was most numerous and scattered in old traditional villages and less in new settlement schemes.

In Japan this scattering of farm plots stemmed from the Taika Reform in the mid-seventh century and some other local reforms. Under these reforms, motivated primarily by a desire to rationalize tax collection for the Emperor's treasury, title to all land officially reverted to the state, and cultivators received life time use righ only. Each male cultivator received two tan (approximately $0.2 \mathrm{ha}$ ) of land when he became six years of age; each female received $2 / 3$ of this amount. The rulers apparently tended this assignment to result in holdings of about 1 ha per family, and initially these holdings were often in one plot. When a right-holder died, however, his rights, reverted to the state for reassignment to a child, often one of another family. Over the years, this resulted in widespread scattering of a single family's holdings. Some other local reforms also contributed to the

Table 5. Number of Field Plots per Farm Household and Size of Field Plots in a Cluster of Villages in the Dry Zone of Sri Lanka.

\begin{tabular}{|c|c|c|c|c|c|}
\hline $\begin{array}{l}\text { Location } \\
\text { (1) }\end{array}$ & $\begin{array}{c}\text { Number of } \\
\text { Farm } \\
\text { Household } \\
\text { (2) }\end{array}$ & $\begin{array}{l}\text { Total } \\
\text { Paddy } \\
\text { Extent } \\
\quad(3)\end{array}$ & $\begin{array}{l}\text { Total } \\
\text { Number } \\
\text { of Plots } \\
\text { (4) }\end{array}$ & $\begin{array}{l}\text { Number of } \\
\text { Plots per } \\
\text { Farm House- } \\
\text { hold }(5)\end{array}$ & $\begin{array}{c}\text { Average } \\
\text { Size of } \\
\text { Plot } \\
(6)\end{array}$ \\
\hline Galkiriyagama & 94 & 56 & 271 & 2. 8 & 0.2 \\
\hline Uduruwa Halmillawewa & 89 & 51 & 159 & 1.7 & 0.3 \\
\hline Kadadewewa & 38 & 49 & 134 & 3.5 & 0.4 \\
\hline Daniyagama & 59 & 36 & 122 & 2. 0 & 0.3 \\
\hline
\end{tabular}

Unit : (3) and (6), Acre

Note : Number of field plots per farm household ranges from 1-10 in the Galkiriyagama Village.

Source : Genewatta, P. 1974.

20) Raper, A. F. 1950

21) Ganewatta, P. 1974

22) Williamson, M. B. 1951 
scattered pattern of holdings. For example the local reform known as "chiwari seido" which existed in some parts of Okinawa until the mid-1930s involved periodic equal division of village lands among the villagers on a qualitative as well as quantitative basis ${ }^{22}$. This system virtually guaranteed wide scattering of holdings, as each right holder held a strip of land of each quality in the area. However some advantages of this pattern seems to have contributed its existance.

a. It tends to insure fair and equal distribution of use rights among cultivators.

b. It serves as a safety factor for individual families in the case of natural disasters. Many types of disasters effect only portions of a village and therefore only part of a man's holdings, and the chances are against complete destruction of a single family's crop by any disaster such as flood or disease apidemic.

The pattern of small scattered field plots plays an important role in the traditional villages in sri Lanka. Mainly it has implications with the tractlevel inequality in the quality of land. Some parts of the paddy tract are preferred from the point of view of fertility, easy availability of water and protection from trespassing animals. Centre parts are much preferred to plots on the two sides of the tract and those further away from the irrigation source. If a farmer has several plots scattered in different parts of the tract, he will give priority to the cultivation of the plots in the fertile and easy irrigable parts. The cultivation of the plots on the less fertile parts receives less attention. Such plots are probably given to tenants or left fallow. Also, it is considered more prestigeous to own even a small paddy plot in the fertile and easy irrigable parts. Under such a situation, groupping of scattered field lots or land consolidation seems to be a rather complicated issue. The farmers would not consent to exchange their paddy plots unless the exchanges have the same quality.

However, farmers' attachment to their farm lands and the attitude of the society toward the land ownership is not so different in Japan. The Japanese farmers too, consider the land ownership as a prestige, and the different quality of the dispersely located farm plots made the land consolidation difficult. However, the land improvement projects which were carried out before or together with the land consolidation made the quality of the scattered field plots somewhat equal. The historical process of the land improvement and the land consolidation shows that the land consolidation has always been preceded by the land improvement. The Cultivated Land Readjustment Law of 1899, which mainly aimed at the improvement of the quality of the cultivated land, promoted something as a by-product, some consolidation of holdings. Work under this law continued steadily until passage of the Land Improvement Law in 1949, which absorbed the function of the earlier law. The function of the projects came into operation under this law has two-fold objectives: to consolidate individual holdings into 3 or 4 plots instead of 15 or 20 , and simultaneously to improve agricultural facilities such as drainage, irrigation and farm roads, serving the land consolidated. 
Such a set-up was necessary because the latter is almost essential prerequisite to the former except in an unusually homogeneous agricultural area. Improvement of agricultural facilities tend to lift the quality and desirability of all land involved closer to the level of the best land. This method seems to be a suitable approach to the land consolidation in Sri Lanka where the inequal quality of the scattered holdings impedes the consolidation.

\section{(ii) Enlargement and rectangularization of field lots}

Before the land improvement projects were undertaken, the Japanese paddy fields were characterized by too small field lots with irregular shape. This particular surface structure of paddy fields is quite identical to that of the present Sri Lankan paddy fields. In the same way as this particular surface structure impeded the efficient operation of machines on Japan's paddy fields, in Sri Lanka too small field lots with irregular shape still impedes the mechanization. Therefore as it has been done in Japan, Sri Lanka too should take necessary steps to enlarge and to rectangularize the field lots. Apart from the facilitation for mechanization, it increases the land productivity too. Enlargement of field lots releases a certain portion of land, which is occupied by levees, for cultivation. Also, the rectangularization of field lots involves straightening of the ditches and roads. It was evident in Yokogashi village near the city of Niigata that straightening of the ditches and roads has resulted in about $10 \%$ increase in crop yields partly from the additional land made available and partly from the more efficient farm practices permitted ${ }^{23)}$. Further evidence can be drawn from the "Ceylon-Japan Rural Development Project-Dewahuwa" (a colonization scheme in Anuradhapura district in the dry zone) which aimed to raise the productivity of paddy lands through consolidation of small field lots into larger ones. This project was executed by the Sri Lanka government with the help of Japanese experts. The net income to farmers after the consolidation of holdings is estimated at Rs. 5,600 per acre as against an average net income before consolidation of Rs. 2, 250 24 .

However, the size and shape of field lots have implications with the prevailing water management problems. Where the irrigation water supply is inadequate and uncertain the farmers tend to keep small field lots because

Table 6. Size of Field Lots in Relation to Their Access to the Irrigation Water in Three Locations in the Dry Zone of Sri Lanka.

\begin{tabular}{|c|c|c|c|c|c|}
\hline \multicolumn{2}{|c|}{ Uda Walawe } & \multicolumn{2}{|c|}{ Kaudulla } & \multicolumn{2}{|c|}{ Padaviya } \\
\hline Top End & Tail End & Top End & Tail End & Top End & Tail End \\
\hline 0.06 & 0.02 & 0.18 & 0.09 & 0.09 & 0.06 \\
\hline
\end{tabular}

Unit : acre

Source: Farrington, J. and F. Abeyratne, 1982.

23) Raper. A. F. 1950

24) Agrarian Research and Trainning Institute, 1976 
the small field lots enables them to retain an adequate volume of water, at least, in a small portion of the holding. For instance, as it is shown in Table 6 the size of field lots in the tail end area of irrigation channels, where the water supply is inadequate and uncertain, is significantly lower than that in the top end area where the water supply is fairly adequate and certain. Therefore the farmers in the tail end area would not consent to enlarge the size of field lots. Therefore, as it has been done in Japan the irrigation system should be improved so that every field lot could get an equal access to irrigation water, if the farmers are to be encouraged to enlarge the size of field lots. The high cost involved in initial land levelling too compells farmers to construct small field lots with irregular shape in hilly areas, because instead of levelling by cutting and moving soils, if they construct small field lots at different levels in parallel with the contours, it reduces the costs but it makes the field lots small and irregular in shape. Therefore in hilly areas, field lots are extremely small and irregular. For instance as it is shown in Table 6 the size of field lots in Uda Walawe area where the topography is rather rough and rolling, the size of field lots is significantly smaller than the other areas. In view of the initial cost of land levelling, any initiation from farmers can hardly be anticipated unless the government subsidizes a sizable share of the cost, as it happened in Japan. In Japan, under the land improvement projects, central government and prefectural governments subsidized, on the average, $45 \%$-SO\% of the total cost, leaving a little share to be paid by farmers. Such a heavy subsidization is particularly necessary for the Sri Lankan farmers whose investable income is very low.

Now, it has become clear that the consolidation of scattered field plots and the enlargement and reshaping of small irregular field lots into larger rectangular ones should be carried out in combination with the improvement of irrigation, drainage, levelling and farm roads which require heavy capital outlay, and therefore, government's subsidies. However, in the case of Japan's land improvement projects while the government provided the legal provisions and financial assistance, the farmers who get the benefit of the improvements, initiated the projects by making proposals to the authorities. Also, they prepared to pay their due share of the cost. The Land Improvement Law is based on a assumption that a project should be undertaken upon a initiative exerted by a group of farmers and the endorsement by the effected farmers. Though the Japanese rationally oriented farmers initiated such progressive projects, the traditionally oriented peasant farmers in the traditional villages in Sri Lanka may, probably, not be so responsive to such legal provisions unless they are provided with financial assistance. For instance, the cultivation Committees which were established under the Paddy Land Act of 1958 have the power to submit plans for improving the efficiency of paddy cultivation, consolidating paddy holdings, establishing collective farms. But in this respect they have not yet become operational. It seems that there are many socioeconomic problems which prevent farmers from taking initiations. Some of them are as follows.

a. In Japan the land improvement projects during the pre-land reform 
period were initiated by land owners. They were eligible for membership in associations organized under the Cultivated Land Readjustment Law, the Agricultural Land Development Law, the Irrigation Association law and the Hokkaido Land Development and Water Use Association Law. They could enjoy the benefit of their effort by raising the land rent. They belonged to a historically developed distinctive social category which was much superior to the tenant farmers. They could initiate such projects and could pay their share of the cost. In the traditional paddy farming villages in Sri Lanka such a distinctive social category of land owners is non-existent. Some farmers, who are unable or not willing to cultivate their total paddy extent by themselves due to the lack of resources, distance from their residence to the particular plot of the holding and poor quality of some of their scattered plots, lease or rent out a certain share of the total paddy extent to, most probably, their relatives. On the other hand, some farmers who are able to cultivate more than they owned, tend to rent in extra land. Under such a setup there is no wide scope to develop a distinctive social class of land owners. The land owners do not have a large investable income, and in contrast to Japan the tenant-owner relationship is not commercial in Sri Lanka. Consequently the incentives for initiations for land improvement could hardly come up from the land owners. On the other hand, the absentee land owners also tend to refrain from investing in land improvement due to the various restrictions which were imposed by the Paddy Land Act of 1958, on the ownership rights.

b. Some tenurial arrangements prevailling in the traditional villages too exert negative impacts on land improvement. Due to the division of land through equal-inheritance, some very small paddy plots were owned by many co-owners. So, these co-owners cultivate the very small plots rotationally (Tattumaru System). Under such a system, no individual co-owner has incentives to make permanent improvements to the land because the benefits of such an effort would be little to each co-owner.

c. Concerning the new settlements, the Land Development Ordinance of 1935 included certain restrictions on the disposal and fragmentation of the holdings given to the settlers. These restrictions are follows.

i. The farmers cannot sell the land except with the prior consent of the government.

ii. The farmer cannot mortgage the land.

iii. The farmer cannot fragment the holding in the inheritance process below a prescribed size. He must nominate a single successor except in certain prescribed cases.

As a result of these restrictions, the settlers have the feeling 
that the land they are given does not really belong to them ${ }^{25)}$. Consequently, they hesitate to invest in land improvement.

d. The present Japanese farmers' interest in land improvement is, to some extent, attributable to the benefits that they could gain from the improved facilities for the mechanization. In Japan, the farmers' time saved by the use of machines could be used for other income-generating jobs whereas in Sri Lanka where the availabilities of such non-farm jobs are limited under current employment conditions, farmers need not to invest in land improvement for the sole purpose of the promotion of mechanization. Also, land improvement reduces the overall running cost of farm machines. In Japan since the farmers themselves are the owners of farm machines they can enjoy the above mentioned benefits of land improvements whereas in Sri Lanka where most of the farmers use farm machines on contract basis, the reduced running cost of machines is enjoyed by the machine owners, not by farmers. Therefore, unlike the Japanese farmers, the Sri Lankan farmers do not have a genuine interest to initiate or to invest in the land improvement in order to facilitate the mechanization.

Japan's experience in land improvement suggests some possible solutions for these problems.

i . Land improvement should be preceded by an effective land reform which promotes all cultivators to the status of owner-operators as it was done in Japan. Ownership right would provide incentives for investment in land.

ii. Tractor ownership should be transferred to farmers through individual or group ownership as it is in Japan. Such an ownership provides incentives to improve their paddy fields so that their farm machines could be used efficiently.

iii. Land improvement should follow the step by step approach which starts from the improvement of irrigation, quality of land, and then to the consolidation of the dispersed small plots into large ones and to enlargement and rectangularization of field lots.

\section{Group Farming}

In the agrarian structure with small holdings in Sri Lanka, mechanization seems to be rather problematic. Since group farming permits to enlarge the scale of farm operations without changing the size of individual holdings, it deserves special attention. In view of the Japan's success in paddy land mechanization and group farming both, and also her similarity with Sri Lanka in terms of the size of operational holdings, Japan's experience seems to be relevant to Sri Lanka. This section is intended to point out the potential significance of group farming for paddy land mechanization in Sri Lanka,

25) Schicklele, R. 1969 
through the Japan's experience.

Current group farming system in Japan seems to be highly diversified in terms of objectives and organizational characteristics. Therefore, it is very difficult to define. However, under the group farming system each farmer does his own farming, but there is group management on crop varieties, timing and methods of cultivation. But different groups have widely different ranges of group activities. In the more progressive groups, cooperative performance of farm practices, group utilization of machinery and agreement on cultivation are closely combined with each other. But, the base of group farming is an agreement on cultivation by farmers. Usually the group includes almost the whole village community. The simplest form of group farming operations is agreement to adopt the same variety, to transplant and apply fertilizer at agreed times and, to manage water and to practise disease and insect control cooperatively. The important thing concerning the group farming is the agreement of participating farmers; it is a kind of group activity based on agreement.

The all cooperative groups for rice production can be divided into four types as follows.
i . Joint-use groups
ii. Joint-crops growing groups
iii. Contract farming groups
iv. Joint holdings

As it is shown in Table 7 there has been an eminent increase in the number of joint-use groups and contract farming groups while the number of joint-crops growing groups has decreased and joint holdings have been stagnant. Tsuchiya (1980) summarized the possible reasons for the failure of

Table 7. Trend in the Number of joint Rice Farming Groups (Cooperative Groups for Rice Production) according to their Types.

\begin{tabular}{|c|c|c|c|c|c|}
\hline & Year & $\begin{array}{l}\text { Joint-use } \\
\text { Groups }\end{array}$ & $\begin{array}{c}\text { Joint Crops } \\
\text { Growing } \\
\text { Groups }\end{array}$ & $\begin{array}{l}\text { Contract } \\
\text { Farming } \\
\text { Groups }\end{array}$ & $\begin{array}{c}\text { Joint } \\
\text { holdings }\end{array}$ \\
\hline Number of & Feb. 1968 & 4,257 & 6,363 & 901 & $519 \quad$ (a) \\
\hline Groups & Aug. 1972 & 5,093 & 5,354 & 2,481 & 467 \\
\hline & July 1976 & 8,970 & 3,371 & 3,439 & $460 \quad$ (b) \\
\hline & Feb. 1980 & 14,929 & 3,037 & 2,227 & \\
\hline Number of & & & & & \\
\hline Constituent & Aug. 1972 & 165,183 & 159,939 & 433,958 & \\
\hline $\begin{array}{l}\text { Farm } \\
\text { Households }\end{array}$ & $\begin{array}{ll}\text { July } & 1976 \\
\text { Feb. } & 1980\end{array}$ & $\begin{array}{l}252,585 \\
302,000\end{array}$ & $\begin{array}{r}104,822 \\
67,700\end{array}$ & $\begin{array}{r}581,605 \\
36,500\end{array}$ & $\begin{array}{r}5,428 \quad(b) \\
-\end{array}$ \\
\hline $\begin{array}{l}\text { Area of Paddy } \\
\text { Fields } \\
\text { covered by } \\
\text { the Groups }\end{array}$ & $\begin{array}{lr}\text { Aug. } & 1972 \\
\text { July } & 1976\end{array}$ & $\begin{array}{l}182,253 \\
319,597\end{array}$ & $\begin{array}{l}152,867 \\
107,956\end{array}$ & $\begin{array}{l}333,667 \\
374,642\end{array}$ & $\begin{array}{l}8,341 \\
7,163\end{array}$ \\
\hline $\begin{aligned} \text { Note : } & \text { (a) A } \\
& \text { (b) } \mathrm{A}\end{aligned}$ & $\begin{array}{l}s \text { of Februa } \\
s \text { of Februar }\end{array}$ & $\begin{array}{r}1970 \\
1975\end{array}$ & & & \\
\hline
\end{tabular}


the cooperative groups as follows.

1. Failure of management

2. An increasing number of part-time farmers.

3. Differences in labour quality.

4. Production control of rice.

5. Decreasing enthusiasm.

6. Enlargement of the farm size.

7. Insufficient finance.

He further states that "the increase in the number of part-time farmers seems to be the main reason, causing an excessive burden of work on the full-time farmers. Profits are distributed according to the land area contributed to the cooperative farms regardless of the fact that the full-time farmers contribute their own labour to cooperative work, whereas the part-time farmers contribute only that of their women and old people. Moreover, the machine operator who is considered to be the most important person in the cooperative farming groups, cannot be certain to work continuously because: (1) the division of labour between co-operative work and work on private farms is difficult to arrange; (2) the machine operator cannot work for the cooperative farm permanently all year; and (3) he inevitably receives a lower payment for his work" (Tsuchiya, 1980, p. 17).

However, the joint-use groups, under which farm machines are owned and utilized jointly, has a tendency of increasing, and also it seems that this type of groups have considerably contributed to the large scale mechanization (from 1966 to present). At this stage, because of the high cost of large scale machines, individual farmers with small farms could not purchase them without government's subsidies. The government's subsidy was not given to individual holders but as a principle, to joint use groups ${ }^{26}$. Also, joint-use of machines enabled the usage of large scale machines at the optimum capacity so that the fixed capital investment could be lowered. In view of the Japan's success in joint-use groups and its contribution to the large scale mechanization in small scale farms, attention will be given in this section only to the joint-use groups.

In this case, joint use-group is defined as a group which is based on a technical agreement plus joint-use of machinery and facilities. "The number of households in one group farming organization varies considerably, with 21-50 households being the most usual size (45\%); another $20 \%$ have 11-20 households. Acreage of paddy in one group farming organization is usually between 10-50 ha; $70 \%$ of all rice group farming organizations fall within that range. Fifty five percent of all rice group farming organizations have their own machinery operators within the group, and $45 \%$ hire operators from out side. Forty five percent of all group farming organizations are managed with on the initiative of a buraku (hamlet), and in these cases all households in the buraku participate. Forty percent of all organizations operate on the initiative of voluntary groups of small farmer members. The re.

26) Kajii, I. 1970 
mainders are cooperative associations etc.” (Kanazawa, 1977, p. 317).

In order to get a close view to the organizational and structural characteristics of the organized groups, and to understand their contribution to promote the mechanization, a selected case study ${ }^{27)}$ and the information gathered from the main author's fact-finding survey, will be considered here.

Aitho-cho, the location of Imoto Group Farming, is a typical farm village in eastern Shiga Prefecture. This village is located near a mountain area which surrounds lake Biwa. Aitho-cho has 919 farms, with 52 full-time farmers (6 $\%)$ and 867 part-time farmers $(94 \%)$. The average size of each farm is 1.09 ha. Total arable land 1,006 ha consists of 919 ha of paddy fields, 44 ha of upland fields, and 53 ha of orchards. The main farm product is paddy, although other products such as tomatoes, grapes, and Japanese tea are produced for marketing.

Out of 41 group farming organizations, 27 are organizations for joint-use of machinery and equipment. Twelve are organizations for crop production, 1 for custom works and 1 for livestock productions. Imoto is the second largest community in this town. Of the total of 114 households 86 are farm households. The average size of farms is 1.16 ha and most farms are engaged in rice, wheat, and vegetable production.

Table 8. Main Machinery and Facilities Owned by Imoto Farming Group.

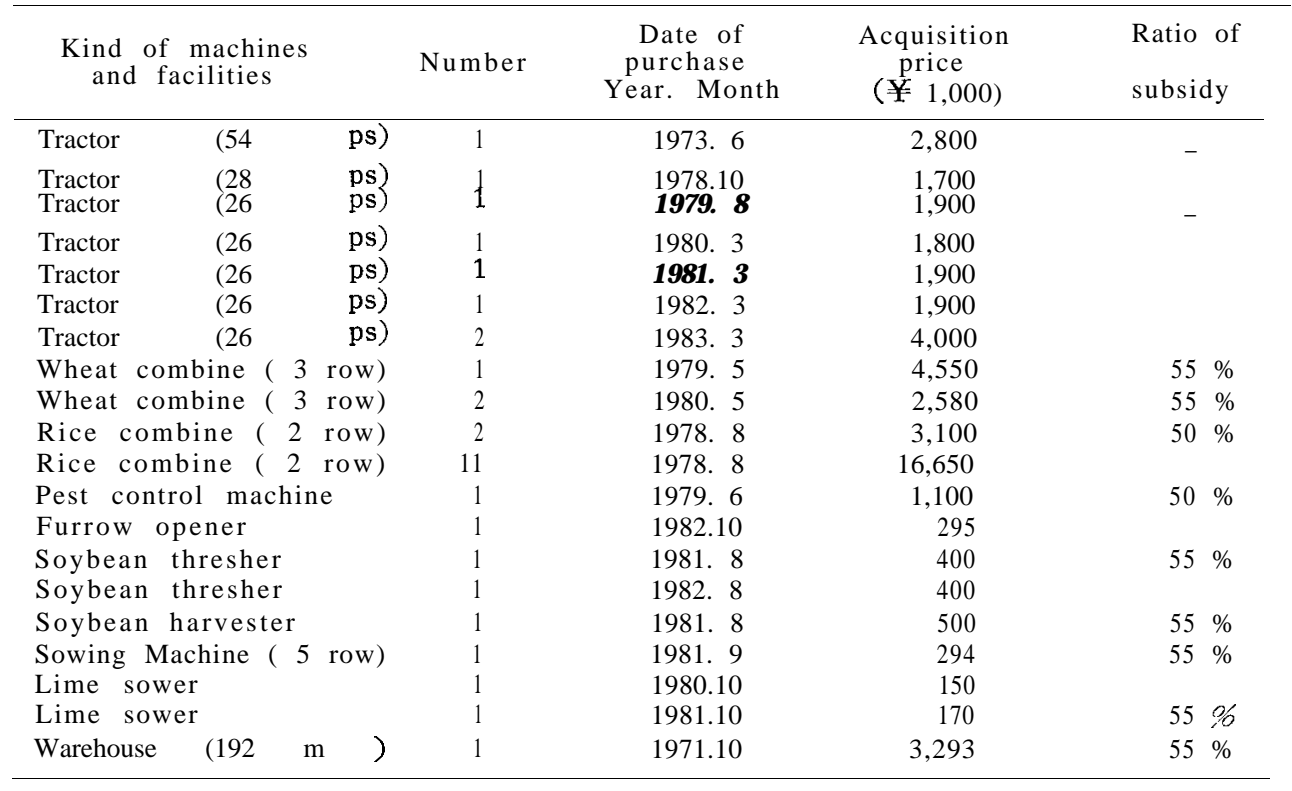

Note : Approximate exchange rates of $¥$ for U. S. \$, 1971: \$1=¥ 316, 1973: \$1=¥ 281, 1978: $\$ 1=¥ 195,1979$ : $\$ 1=¥ 219, \quad 1980,1981$ and $1982: \$ 1=¥ 220-240$.

Source : Nishimura, 1984.

27) Nishimura, H. 1984 
In 1971 this group was established to create an efficient joint-use of farm machinery under the programme of the Second Agricultural Structure Improvement Project. The group was established on the basis of the community, and it consists of all members of the community. In this group $85 \%$ of the farmers are part-time farmers whose income mainly come from non-farm sources.

The prominent effect of the group system was the efficient utilization of machines. The group owned seven tractors, four combines and other machines (Table 8). Combines, a soybean harvester, and a soybean sowing machine were borrowed from the Agricultural Cooperative Association to supplement the group works. In this community, ten 2-row combines as well as 42 transplanting machines are owned by individual farms. This large number of transplanting machines owned by individual farms may bring us into farmers' feelings.

The members of executive staff of the group consist of a director, four associates (including accounting, farming, irrigation, and vice director). The group is divided into 8 sub-groups. The chief of each group takes the initiative in the group activities, and the functions of each group is to make farm management plan including the land use planning of the paddy field in the community and to do work from the ploughing to the harvesting in the rice production.

Since the majority of the farmers are part-time farmers, a substantial amount of work has been carried out by the full-time farmers and a limited number of part-time farmers. About $70 \%$ of the farmers are engaged in cooperative group works for less than five days. This means that majority of the cooperative works is done by limited members. Actually, only $35 \%$ farmers can operate the machines.

There is no work contract between communities. Table 9 shows the hectareage of the works done by the group in 1983. Transplanting is carried out individually because of seasonal limitation. This is the reason why transplanting is done on individual basis.

This case study summarizes the effects of cooperative use of farm machines as follows.

(1) There is a tendency for farmers to have their own individual machines and equipment, but the farmers in this community have a mutual understanding not to buy machines individually except transplanting machines. The fundamental objective to establish a group farming system is to avoid over investments and/or duplicated investments at the private level. This system realized scale economies of the investment of machines especially the basic machines works such as ploughing or harvesting. Lower costs of machinery have resulted from the joint-use of machinery. Many small farmers, who are usually part-time farmers receive tremendous benefits. The share of machinery expenses in the production cost of rice in Japan amounts to nearly one fourth. Farmers in this community estimate the total 
Table 9. Hectareage of the Works done by Imoto Farming Group (Kinds of Enterprises and Works).

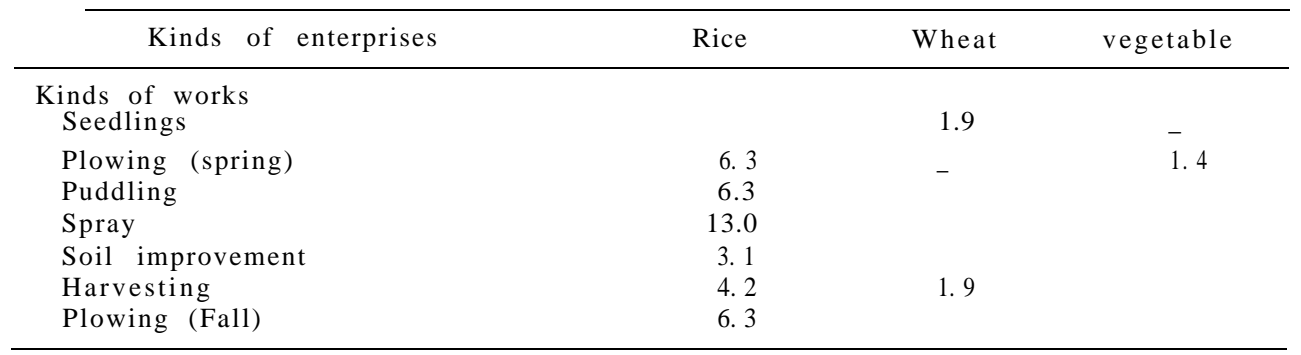

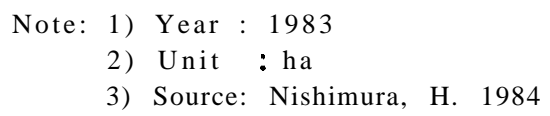

production cost of rice to be about two third of that in Shiga Prefecture.

(2) Rice yields per ha were not much different from the regional average. Labour input is estimated at less than $50 \%$, showing the large labour-saving effect. An increase in the charge for machine-use however, caused a little decrease in the farmer's income. There are increases in total production and productivity of the crops due to the advanced technology and better management from capable farmers.

(3) The part-time farmers seem to be free from labour due to the improved labour saving technology.

(4) Full-time farmers could increase the size of operation due to their higher capability in farm management. The average farm size of full-time farmers appears to have risen from 2-3 times.

(5) There are effects of rational land use, adopting a better work schedule, and taking reasonable production planning.

(6) It is fairly successful to overcome the difficulties which were caused by the rice production control policy. Farmers can use the converted land effectively and control the damages which might be caused by non-cultivation.

(7) The meeting makes it easy for farmers to have consolidated views of community management toward looking for a better life.

Thus, group farming is a means to prevent the over-investment on machinery. Farm mechanization allows the saving of labour requirements in the production process. Furthermore farmers in the community wish to lessen the heavy machinery cost by joint use while at the same time holding their freedom in individual farm operations. Part-time farmers who now make up the majority have benefit of less labour requirement, and eventually less production cost due to the better farm management from full-time farmers. 
To supplement this case study and to get a real impression of group farming the main author himself has conducted a brief fact-finding survey in the Dimon Wheat-Barley Producing Group Farming Organization in Maibaru Town in the Itoshima County of the Fukuoka Prefecture. This survey was based on two personal visits to the farming area and on an open-interview with the group leader and an informal group discussion with five members of the group. The group leader was interviewed at his residence, and the group discussion with other members was held at the office room of the organization.

This group was established in 1974 in order to achieve following objectives.

1. To reduce the cost of machinery.

2. To get government's subsidies for farm machinery and facility.

3. To expand the farm scale.

Today its membership consists of 7 full-time famers and 2 part-time farmers (one first class part-time farmer and one second class part-time farmer). Consequently, today this group is dominated by full-time farmers.

The total farm land under the control of this group is 17 ha. All farm operations are performed according to a properly planned work schedule; and all operations except transplanting are done by jointly owned machines. A number of group farmers serve as machine operators. They are paid at the rate of $¥ 5,000$ /day for every operation. When the machines are free from group members' farm operations, the machines are hired for custom works. In such a case, the machine and the operator, who is a member of the group, both are provided as a single unit.

Management structure of this group is quite similar to the former case. It has been realized that the present performance is successful. The leader as well as other members expressed their satisfaction with the joint ownership and joint-use of farm machines. According to them although there were some serious problems at the beginning, in the course of time, they managed to overcome them, and at present everything is going on smoothly. Frequent discussions, once a month at the beginning and now once per every two months, considerably assisted to promote the mutual understanding. As a result, now they all work together as a family.

However, the successful performance of the group activities in this organization seems to be considerably attributable to its leadership. It has been understood from the personal discussions with the leader and with the other members that the leader's managerial capacity is considerably responsible for the present success of the group organization.

Group farming, however, is reported to be faced by many problems within Japan. Many of these problems stemmed from 2 main sources as follows.

1. Dichotomy between part-time farmers and full-time farmers. Imbalance of the distribution of responsibilities and benefits between these two categories is often reported. While the full-time farmers bear a greater part of responsibilities, part-time farmers enjoy much of the benefits. 
2. Declining number of experienced and active farmers who can give the leadership. Due to the rapid outflow of farm population to the non-farm sector, well-experienced full-time farmers are declining in number. Since the successful operation of group farming is mostly dependent upon the quality of leadership, the lack of leading farmers has given rise to many problems.

However, these phenomena are not noticeable in Sri Lanka. Therefore the problems which are confronted by the group farming in Japan are unlikely to occur in Sri Lanka. Therefore, it seems that it is advisable to consider the relevancy and feasibility of the group farming.

In Sri Lanka where the paddy farm size is rather small, if farm mechanization is done under individual ownership it would remarkably raise the fixed capital per unit area. Also, due to the rather small farm size, machinery owners would not be able to utilize the full capacity of machines. For a capital-scarce country like Sri Lanka, under-utilization of capital is extremely disadvantageous. Farm mechanization through joint ownership, as it was seen in the observed case studies, would considerably reduce the fixed capital investment per farm. Apart from this, due to the low family income of small farmers in Sri Lanka, machinery will be acquired by the rich class which has easy access to capital. Such an accumulation of tractor ownership into the hands of a few, leads to the accumulation of cultivation rights over land which results in greater income inequality. It is a well observed fact that farm mechanization in developing countries enriches the rich tractor owners and makes poorer the poor farmers. However, the farm mechanization through joint ownership of machines would avoid this problem because it prevents the machinery ownership from concentrating into the rich class, and it enables the small farmers to keep their own machines under the group ownership as it was observed in Japan. In such case it would enable small farmers to use tractors at a lower cost and to raise the family income.

Mechanized land preparation is often blamed for its relatively low quality of performance ${ }^{28)}$. It is said that mechanized land preparation leaves unploughed strips and corners, and piles of soils here and there on the field. Also, tractors break levees when they shift from one field lot to another. Imperfect levelling is another criticism against tractor utilization for ploughing. However, tractor operators' lack of interest in doing their job perfectly is often noticed by farmers. In the case of contract land preparation which is popular in Sri Lanka the tractor and the operator both are hired out as a single unit. Since the tractor operator is employed by the owner, he is directly responsible to the owner. The farmer who hire the tractor is not in a position to exert any pressure upon the operator in order to get the standard of the performance of the farm operation to his own level of satisfaction. The tractor operator often tends to complete the assigned operation within the possible shortest time and to commence the next contract work soon. The resulting hasty operation leaves the performance below the per.

28) Goldsmith, E. 1982 
fect level. Therefore, further attempts to promote the mechanization under the individual ownership may be retarded by the observed low quality of work performance of tractors. However, if the mechanization is promoted under joint ownership, a number of group members who are responsible to all other members, serve as operators. On the other hand, all the users, as owners of the machines, have the right to command the machine operator to bring the quality of performance to their own standard. Also, in view of the collective responsibility and mutual understanding among members, the machine operating member could be anticipated to make genuine effort to improve the level of work performance. Therefore the group approach may be a suitable measure to solve this problem.

Apart from this, some problems faced by the paddy land mechanization in the central mountain area could be solved by the introduction of the group farming system. The terraced paddy fields on mountain slopes have very small field lots. Therefore large scale tractors cannot be properly used. Only the small hand tractors are suitable for paddy fields with small lots. "On an average a two wheeler has a length about 6 feet and breadth of 2 feet. The compact size has the advantage of small turning radius about 2 feet, which has led to its convenient use in small liyaddes (field lots) and in those having difficulty of access" (Sathasivampillai and Sivasithamparam, 1971 , p. 3). However those who have disposable income to purchase tractors, relying on non-farm custom works, prefer large scale tractors. Therefore, small scale tractors (two wheelers) which are suitable for paddy lands on slopes, are not adequately available in the central mountain area. On the other hand, the farmers, due to their lack of access to capital, cannot purchase tractors or power tillers which are suitable for the local conditions. Therefore, mechanization under individual ownership would not benefit the farmers in the central mountain area. However, it seems that the group approach to mechanization which enables some farmers to select and to purchase the machines which are suitable to the local conditions, would benefit the farmers in this area.

Tractor usage for paddy land preparation is sometimes blamed for the delay in the commencement of land preparation becuse some tractor owners often fail to provide tractors for their customers at the required time due to the difficulties in getting all contracts into a well organized plan. Requests coming at different times to till paddy fields located at different areas, make the proper programming extremely difficult. However, joint-use of tractors, as it was observed in Japan, enables proper programming for farm machines so that all members could use machines in time.

Feasibility of the introduction of group farming to the paddy farming sector in Sri Lanka will be assessed here in the following ways.

a. Observation of the presently existing and already existed various kinds of group activities among the paddy farmers in traditional villages and the assessment of their potential value for the successful introduction of group farming.

b. Evaluation of the findings of an experimental study on group farm- 
ing which was conducted by the Agrarian Research and Training Institute in Beminiwatta area in the Kegalle district in Sri Lanka.

c. Investigation of the problems of introducing group farming, and possible solutions from Japan's experience.

(a). Common agreement and cooperative actions in farm operations within farmers' groups and the joint-use of the jointly owned capital equipments are the salient features of the group farming. If any of these features are evident in any kind of previously existed or presently existing tradition pertaining to farm operations, it may undoubtedly facilitate the introduction and implementation of group farming.

Agreement among farmers who cultivate paddy in the same irrigated tract, which is the basic principle of group farming, has been well known to Sri Lankan paddy farmers in traditional dry zonal villages. It has been a long standing tradition among them to come into an agreement on the time schedule of major cultivation operations and on the variety of seeds to be sown. During the colonial era, legal provisions also existed under the Irrigation Ordinance for the farmers to perform operations such as ploughing, sowing, harvesting, fencing and maintenance of irrigation work in accordance with an agreed calendar of work. Paddy Land Act of 1958 also made similar provisions. Another kind of tradition called bethma which has been practising in the dry zonal traditional villages over centuries, also called for a kind of agreement and some collective responsibility. In the case of unexpected drought, according to this tradition, in order to make the best use of limited water in the small village tank, which is irrigation pond, the farmers who cultivate under each tank come into an agreement to cultivate only a portion of their paddy holdings, in relation to the availability of water in the tank.

Cooperative farm operations, which is a dominant feature in modern advanced group farming, can be found in the $a t t a m a^{29}$ institution in Sri Lanka. Since it has been in practice over centuries, in view of the farmers long standing adherence to such a cooperative action, modern concept of group farming is likely to be acceptable to traditional farmers. In the case of attama, the individually owned capital equipments and draught animals are commonly used. In the case of advanced group farming, quite similarly, capital equipments (farm machinery) are jointly owned and jointly used. Therefore, farmers' experience in joint-use of capital equipments may facilitate the introduction of the joint-use groups into the traditional paddy farming villages.

(b). The first group production experiment which was conducted in Maha 1975/76 at the Agrarian Research and Training Institute's field laboratory at Baminiwatta aimed at the following objectives ${ }^{30)}$.

29) Tradition of reciprocal exchange labour. For further details, refer Ulluwishewa, R. and K. Tsuchiya 1984 The Disintegration of a Traditional System of Exchange Labour and Mechanization of Paddy Land Preparation in Sri Lanka Journal of the Faculty of Agriculture, Kyushu University, 29(2-3):117-138

30) Goonarathne, W., Olesiak, K. P. and M. Samad 1977 
1. To study how farmers could be organized and activated to work in groups and how rural institutions could be made to serve the small farmers effectively.

2. To explore the ways by which farmers and rural institutions could be brought together to work on a common production programme.

3. To demonstrate to the farmers of the area and to members of rural institutions the advantage of group production.

This area is located in the wet zonal mountain area. Agriculture is the main economic activity with $79 \%$ of the farmers engaged in paddy cultivation. Population pressure on land is accute. The availability of land per head of population is only 0.27 acres. Paddy cultivation is practised mainly under rainfed conditions. Although most farmers adopt improved cultural practices the absence of uniformly high standards of management results in low average yields (34.6 bu/acre Maha 1973/74).

Though this experimental study was conducted in two stages, only the first stage of the experiment which was conducted in a small village called Molligoda is considered here. The paddy tract of Molligoda was 16.2 acres in extent operated by 18 farmers whose individual holdings ranged from 0.5 to 1.25 acres. The farmers operated the land on an individual basis with very little coordination in their farming operations. Some did adopt better cultural practices but not systematically. Sowing and transplanting were done at different times. Different aged varieties of paddy were grown which had varying times of maturity and different degrees of resistance of pests and diseases. All these coupled with inefficient water management led to low yields.

Concerning the internal structure, for the sake of brevity and easy understanding, only the organizational differences between the already mentioned two Japanese case studies and the Molligoda farmers group will be mentioned here.

i. While in the case of Japan a farmers' group was a self-governed body, the Molligoda farmers' group was a group which was organized and manupulated by external institutions such as ART1 and two other local level institutions (Agricultural Productivity Committee and The Cultivation Committee).

ii. While in the Japanese case, all group members were collectively responsible for credits and for subsidies they obtained, in the Molligoda case the group members were individually responsible.

iii. In the Japanese case, each member was responsible to the group leader and to his fellow members for his adherence to the common production programme whereas in the latter case, each member was individually responsible to the Agricultural Productivity Committee, because each member individually signed for agreements with that committee. Each member agreed with the committee to perform all agricultural operations according to the agreed calendar and to repay the credit in time, while the committee agreed to provide credits in time.

iv. While all farm operations were mechanized in the former case, 
human labour was dominant in the latter case, except a little use of jointly hired sprayers.

It is important to mention here the fact, that the only group action in the Molligoda case was the members' adherence to the commonly agreed production programme and the main advantage that the members enjoyed by being members of the farmers' group was the timely receipts of inputs on credits.

This experimental study obtained following results :

i . Farmers as a group were able to obtain their inputs in time, reduce transport cost, have access to sprayers and other equipments and also to adopt improved farm techniques.

ii. In accordance with the common production programme, all group members planted the same variety, used fertilizer at the correct time in recommended quantities, adopted routine pest and disease control measures. As a result, the yield increased from $32 \mathrm{bu} /$ acre in Maha 1974/75 to $65 \mathrm{bu} /$ acre in Maha 1975/76. The variation in yield among group members was small and ranged from 59-72 bu/ acre.

iii. The extention workers were able to communicate with farmers more effectively as a group than individually.

Although this experiment did not make effort to introduce the joint. ownership and joint-utilization of tractors, its success in keeping the members adhering to the common production programme which is the major basic principle of group farming suggests that there is a scope for further development of group farming. At a cetain stage of such a development, introduction of joint ownership and joint-use of tractors would be possible.

(c). However, attempts made to introduce group farming into Sri Lankan traditional farm sector is likely to be faced by some problems. Farmers' lack of interest in organizing themselves into groups is quite noticeable in Sri Lanka. It seems that more attractive incentives are needed to motivate farmers for the promotion of group farming. Japanese experience in group farming also suggest the significance of the incentives. In Japan, since the inception of the progress of group farming, subsidies have considerably stimulated farmers to organize themselves into groups. For example, the subsidies on machinery provided by the central and prefectural governments both were given to farmers' groups, not to individuals. So, the farmers' desire to get the benefit of subsidies for mechanization induced them to organize themselves into groups. From the central government, the First Agricultural Structure Improvement Project (1962-71), Second Agricultural Structure Improvement Project and the Joint Farming Development Project provided subsidies for the introduction of farm machinery and facility through the farmers' groups. "According to a survey conducted in 1977, 90\% of joint rice farming groups were those established availing themselves of an opportunity to receive a subsidy project of the national government" (Kajii, 1979, p. 11). It has been learned from the personal communication with the leader of the Dimon Group that one of the factors which made them organize into a group was the benefits 
that they could gain from subsidy projects. This Japanese experience suggests that if the Sri Lankan farmers are to be encouraged to organize themselves into groups, the state should change its present policy of providing subsidies to individuals, and it should adopt a new policy to provide subsidies to farmers' groups.

In Japan, farmers' groups are legally recognized, and the leaders have the authority to deal with other institutions and individuals on behalf of their groups. In the absence of such a recognition by the state under a suitable legal framework, any voluntary emergence of farmers' groups is highly unlikely. In Japan farmers' groups enjoy a definite legal status as they are registered with the agricultural cooperatives. This fact points out the significance of the legal recognition.

Another problem which would hamper the formation of farmers' groups in Sri Lanka is the tenurial complications. Tenants without security and freedom for decision making may find effective participation in group activities difficult. Group activities may become difficult if there are many co-owners to the farm land because in such a case the co-owners cultivate on rotational basis so that the actual operator changes every season or year. Furthermore, the operation of a large number of paddy plots in different tracts or areas may also complicate the organization of farmers' groups. Even in Japan the tenurial situation was quite complicated before the implementation of land re form and land consolidation projects. The post-war land reform in Japan mainly brought about a change in the titles to land and the pattern that emerged was one of individual owners. Therefore, it seems that the land reform has facilitated the formation of farmers' groups by giving the ownership of the land to the operators. After that, land consolidation projects assembled the dispersely located small plots, facilitating joint farm operations. This Japan's experience suggests to Sri Lanka that rigid land reform and land consolidation projects are necessary for the successful introduction of group farming.

A large share of the many kinds of group activities in Japan is built on the basis of 'buraku' (hamlet). The buraku was the smallest unit of organized farmers and also the terminal unit of water management. The traditional exchange-labour system called $U i$ was functioned on buraku level. A traditional buraku consisted of 20-30 farm households (in some cases 30-50), is very suitable size for group water utilization and management. The buraku's counterpart in Sri Lanka gama (village) was the smallest unit of farm settlements and also every gama especially in the dry zone, is established on the basis of an irrigation water outlet. Attama, the Japanese $U i$ 's counterpart in Sri Lanka was functioned at the gama level. In buraku and gama, there were traditional leaders, usually the large farmers. Insofar as the buraku inhabitants' long experience in cooperative operations in transplanting under $\mathbf{U i}$, and the traditional leadership have facilitated the later formation of the farmers' groups at buraku level, in Sri Lanka, gama inhabitants' experience in cooperative operations in ploughing and harvesting under attama, and the traditional leadership may facilitate the gama-level farmers' groups. Since farmers in buraku 
and gama both get irrigation water from their own irrigation reservoirs, their own-level group activity facilitate the maintenance of the tract level uniformity and proper adjustments of the depth of water on the fields at different growth periods. These facts suggest when Sri Lanka makes attempts to form farmers groups, in view of the Japan's success in buraku-level group farming, gama may be the best unit on which farmers groups could be organized. However, some farmers in a gama, have their paddy plots in a number of adjacent gamas too. Therefore, before the introduction of gama-level group farming, land consolidation is necessary to bring the individual's all paddy plots into the gama where they reside. In large scale irrigation schemes where the gama-like small units are not existent, in view of the convenient farm level water control, irrigation terminal units may provide a suitable size of units for group activities. For example, under the Mahaweli Development Project which is the largest irrigation scheme in Sri Lanka the units of farmland of 12-20 ha commanded by one measurable source of water called the Turnout Gate may be a best size of unit to organize farmers groups ${ }^{31}$. Every Turnout Gate unit consists of 12-20 farmers, and all of them get irrigation water from the same terminal. Therefore, it benefits to all if they organize themselves into groups to follow a common production programme and to jointly own and utilize farm machines and facilities.

In the light of the forgone discussion it can be concluded that the organization of farmers' groups on the basis of agreement for common production programme plus group ownership and utilization of farm machines has a considerable potential value to solve some important problems involved in the farm mechanization; and also there are reasonable grounds to assume that such an attempt would be successful if the initiative comes in the proper way. However, more grass-root level feasibility studies are necessary to identify the proper way.

It has become apparent that, in Japan the modification and improvement of imported agricultural machines, land improvement and group approach to tractor ownership, have considerably assisted to avoid the circumstances which would have given rise to many problems, and Sri Lanka's failure to adopt such measures has caused many problems. Also, it has become clear that these measures have greater capacity to solve some of the serious problems.

\section{CONCLUSION}

The poor quality of work performance of tractor ploughing, which is widely accepted by dry zone farmers, has been found to be considerably attributable to the Sri Lanka's failure to improve the imported tractors and attachments and to adapt them to the local field conditions, and to improve the field conditions to make them fit to the modern machines and implements. Therefore modification and improvement of imported farm machines, and the improvement of paddy field conditions, have potentials to solve this problem

31) Khan, S. S. 1982 
as it was seen in Japan. Besides, transfer of tractor ownership to farmers through joint-ownership seems to have capacity to eliminate the prevailing gap between tractor owners and tractor users, and by doing so, to improve the farmers' quality of living. Japan's experience in land improvement and group farming points out a suitable approach towards the successful implementation.

Thus, it seems that Sri Lanka has many things to learn from Japan's experience in mechanization. However, Sri Lanka's present position in the international economy and her own economic situation is much different from that of Japan when Japan was at the introductory stage of mechanization. Therefore, Japan's experience can only point out the proper way and possible measures. It should be categorically stated that Sri Lanka should not adopt the Japanese model as it is. More grass root-level studies are necessary to assess their suitability and feasibility.

\section{ACKNOWLEDGEMENTS}

The authors wish to thank Dr. Tsunemasa Kawaguchi and Dr. Toshimi Umeki, Associate Professors and Dr. Satoshi Kai, Assistant Lecturer of the Department of Agricultural Economics, Kyushu University for their constructive comments on the first draft of this paper. The main author wishes to extend his gratitude to messrs Tsuneo Kobayashi and Kazuhiko Yamashita, who helped him with the fact-finding survey in the Dimon Group Farming Organization. Mr. Kishihara Toshiki, the leader of the above mentioned farmers' group and its other members who were so patient and cooperative in answering the questions deserve special thanks.

\section{REFERENCES}

Agrarian Research and Training Institute 1976 Land Settlement in Sri Lanka, Research Study Series, No. 16, ARTT. Colombo

Brohier, R. L. 1975 Food and People. Colombo

Farrington, J. and F. Abeyratne 1982 Farm Power in Sri Lanka. Department of Agricultural Economics and Management, University of Reading, Reading

Ganewatta, P. 1974 Fragmentation of Paddy Land. Occational Publication Series No. 5, ARTI, Colombo

Goldsmith, E. 1982 Traditional Agriculture in Sri Lanka The Ecologist, 12: 209-216

Goonarathne, W., Olesiak, K. P. and M. Samad 1977 Group Production -A Case Study. Occasional Publication No. 14, ARTI, Colombo

Hayakawa, S. and Y. Watanabe 1970 Examples in Group Farming Operation and JointUtilization. In "Symposium on Farm Mechanization", ed. by Tropical Agricultural Research Center, Ministry of Agriculture and Forestry, Tokyo

Hemmi, K. and K. Atumi 1981 Mechanization of Small Scale Peasant Farming. Report No. 21, Agricultural Development Council, New York

Kajii, I. 1979 Joint Rice Farming in Japan. The paper presented at the FFTC/ASPAC Seminar on "Joint Rice Farming" October 16-21, Tokyo

Kanazawa, N. 1977 Problems and Directions of Agricultural Group Activities in Japan. In "Cooperative and Commune", ed. by P. Doner, University of Wisconsin, pp. 331-325 
Karunanayake, M. 1977 The Attitude of Peasants to Land Consolidation -A Case Study of a Dry Zone Village in Sri Lanka National Geographer, 9 (1) : 25-34

Kawashima, T. 1984 Changes of Farm Practice for Rice Cultivation - From Manual Practice to Mechanical O ne - Farming Japan, 18 (2) : 49-55

Khan, S. S. 1982 Organizing Farmer Groups in Mahaweli Ganga Agricultural Administration, 11: 303-308

Kisu, M. 1970 Technical Problems in Mechanization of Soil Preparation. In "Symposium on Farm Mechanization" ed. by Tropical Agricultural Research Center, Ministry of Agriculture and Forestry, Tokyo

Nagata, K. 1973 The Problems on the Land Readjustment and Reorganization of Rice Culture System. (in Japanese) Journal of the Central Agricultural Experimental Station, 18: 135-196

Nishimura, H. 1984 The Cooperative Use of Farm Machinery in Japan - Based on a Case Study of Rice Farming in Shiga Prefecture. The paper presented at the FFTC sponsered seminar on the Efficient Farm Mechanization of the Small Farms, July 9-12, Seoul

Pillainayagam, G. M. 1982 Research into Farm Power and Equipment in Sri Lanka. The paper presented at the Regional Seminar on Farm Power, 25-29 October, ARTI, Colombo

Raper, A. F. 1950 The Japanese Village in Transition. General Headquarters, Supreme Commander for the Allied Powers, National Resource Section, Report No. 148, Tokyo

Sakai, J. 1984 (a) Technological Review of Mechanizing Japanese Small Farms for Tractorization with Field Equipments. The paper presented at the FFTC/ASPAC seminar on The Efficient Farm Mechanization of the Small Farms, July 9-12 Seoul

Sakai, J. 1984 (b) Technological Characteristics of Japanese Animal-D rawn Ploughs for Mechanizing Small Farms. The paper presented at the National Symposium on Machinery for Agriculture, August 24-26, Colombo

Sathasivampillai, R. and R. Sivasithamparam 1971 The Role Two-Wheel Tractors in Sri Lanka's Farm Power Requirements Tropical Agriculturist, 128: 1-12

Sawada, S. 1973 Technological Progress in Japanese Agriculture. (in Japanese) Sawada Shujiro Kyoju Taikankinen Gigyokai

Schicklele, R. 1969 Land Settlement Policy in Ceylon In 'Ceylon Papers on Agricultural Development and Economic Progress 1967-70" ed. by University of Ceylon, Peradeniya

Taniyama, S. 1975 Land Consolidation in Paddy Fields. In "Symposium on Water Management in Rice Fields" ed. by Tropical Agricultural Research Center, Ministry of Agriculture and Forestry, Tokyo

Taylor, S. G. 1945 Administration Report. Department of Irrigation of Sri Lanka, Colombo

Tsuchiya, K. 1976 Productivity and Technological Progress in Japanese Agriculture. University of Tokyo Press, Tokyo

Tsuchiya, K. 1980 The Development of Farm Mechanization After the Second World War. The paper presented at the seminar on The Mechanization of Small Scale Peasant Farming, July 7-11 Sapporo

Ulluwishewa, R. and K. Tsuchiya 1983 The Socio-Economic Study of the Draught Animal Power in the Dry Zone of Sri Lanka. A Case Study: Hureegama Village Journal of the Faculty of Agriculture, Kyushu University, 28 (1) : 51-70

Ulluwishewa, R. and K. Tsuchiya 1984 A Study of the Motivating Factors for Farm Mechanization in the Dry Zone of Sri Lanka. A Case Study: Unagaswewa Village Bulletin of the Tropical Agriculture, Kyushu University, 7:91-117

Williamson, M. B. 1951 Agricultural Programmes in Japan 1945-51. General Headquarters, Supreme Commander for Allied Powers, National Resource Section, Report No. 148, Tokyo

Yukawa, K. 1975 Distribution System of Irrigation Water in Japan. In "Symposium on Water Management in Rice Fields" ed. by Tropical Agriculture Research Center, Ministry of Agriculture and Forestry, Tokyo 